\title{
Digital Health Promotion and Prevention in Settings: Scoping Review
}

Anna Lea Stark ${ }^{1 *}$, MSc; Cornelia Geukes ${ }^{1 *}$, DrPH; Christoph Dockweiler ${ }^{2}$, Prof Dr

\footnotetext{
${ }^{1}$ School of Public Health, Centre for ePublic Health, Bielefeld University, Bielefeld, Germany

${ }^{2}$ Faculty V: School of Life Sciences, University of Siegen, Siegen, Germany

*these authors contributed equally
}

\section{Corresponding Author:}

Anna Lea Stark, MSc

School of Public Health

Centre for ePublic Health

Bielefeld University

Universitätsstraße 25

Bielefeld, 33615

Germany

Phone: 4952110667859

Email: lea.stark@uni-bielefeld.de

\begin{abstract}
Background: Digital technologies are increasingly integrating into people's daily living environments such as schools, sport clubs, and health care facilities. These settings play a crucial role for health promotion and prevention because they affect the health of their members, as the World Health Organization has declared. Implementing digital health promotion and prevention in settings offers the opportunity to reach specific target groups, lower the costs of implementation, and improve the health of the population. Currently, there is a lack of scientific evidence that reviews the research on digital health promotion and prevention in settings.
\end{abstract}

Objective: This scoping review aims to provide an overview of research targeting digital health promotion and primary prevention in settings. It assesses the range of scientific literature regarding outcomes such as applied technology, targeted setting, and area of health promotion or prevention, as well as identifies research gaps.

Methods: The scoping review was conducted following the Levac, Colquhoun, and O'Brien framework. We searched scientific databases and gray literature for articles on digital setting-based health promotion and prevention published from 2010 to January 2020. We included empirical and nonempirical publications in English or German and excluded secondary or tertiary prevention and health promotion at the workplace.

Results: From 8888 records, the search resulted in 200 (2.25\%) included publications. We identified a huge diversity of literature regarding digital setting-based health promotion and prevention. The variety of technology types extends from computer- and web-based programs to mobile devices (eg, smartphone apps) and telemonitoring devices (sensors). We found analog, digital, and blended settings in which digital health promotion and prevention takes place. The most frequent analog settings were schools $(39 / 200,19.5 \%)$ and neighborhoods or communities $(24 / 200,12 \%)$. Social media apps were also included because in some studies they were defined as a (digital) setting. They accounted for 31.5\% (63/200) of the identified settings. The most commonly focused areas of health promotion and prevention were physical activity $(81 / 200,40.5 \%)$, nutrition $(45 / 200,22.5 \%)$, and sexual health $(34 / 200,17 \%)$. Most of the interventions combined several health promotion or prevention methods, including environmental change; providing information, social support, training, or incentives; and monitoring. Finally, we found that the articles mostly reported on behavioral rather than structural health promotion and prevention.

Conclusions: The research field of digital health promotion and prevention in settings is heterogeneous. At the same time, we identified research gaps regarding the absence of valid definitions of relevant terms (eg, digital settings) and the lack of literature on structural health promotion and prevention in settings. Therefore, it remains unclear how digital technologies can contribute to structural (or organizational) changes in settings. More research is needed to successfully implement digital technologies to achieve health promotion and prevention in settings. 
(J Med Internet Res 2022;24(1):e21063) doi: 10.2196/21063

\section{KEYWORDS}

setting approach; health promotion; health prevention; eHealth; internet; behavior change; web-based intervention; technology; mobile phone

\section{Introduction}

\section{Background}

The setting approach is considered a main strategy of health promotion [1]. For its practical implementation, it is important to use an operationalizable and consensual concept of a setting. However, various and sometimes divergent definitions exist [2]. A setting can be defined as a relatively permanent social context of which the members are subjectively aware [3] or as a "...place or social context in which people engage in daily activities in which environmental, organizational and personal factors interact to affect health and wellbeing" [4]. Up to now, there has been a lack of a conceptual and theoretical framework of the setting approach [2]. Health-promoting organizational development therefore often makes use of sociological organizational theories, especially systems theory and structuration theory. Furthermore, organizational change theories are applied, including, for example, the diffusion theory of Everett Rogers or the model of change proposed by Kurt Lewin [5]. Public health theories and models are also used for the implementation of setting-based or complex health-related interventions partly considering structural aspects of the implementation, such as the PRECEDE-PROCEED model [6].

To gain a better understanding of what setting-based health promotion and prevention might look like in practice, Whitelaw et al [7] developed a categorization of 5 different types. The passive model focuses on individuals and their health-relevant behavior. The setting is used as an access to individuals and groups. The active model includes interventions that focus on the health behavior of individuals. However, it assumes that some behavior changes are inhibited or enabled by structural features of the setting. Thus, structural modifications are required. The vehicle model focuses on individual health issues, but interventions and projects are intended to initiate systemic changes. The projects serve as door openers for developments at other levels of the setting. The focus is on structural factors and their influence on health, even if individual health issues are addressed first. In the organic model, social systems are understood as the product of the processes of individuals and groups living and acting together. Interventions result in systemic changes that affect the communication culture and community values in the setting. The setting is understood as the framework for health, which can be influenced by setting members. Participation and empowerment of people to affect their environment are key concepts. The comprehensive model assumes that the setting affects health. Settings are understood as superordinate systems in which the individual has hardly any opportunities to affect them himself. Interventions are often implemented from the top down $[1,7]$.

In the last decade, digitization has had a major impact on everyday life in settings and on the research and practice of setting-based health promotion and prevention. Approximately
$77 \%$ of the population uses the internet on a daily basis, and approximately $90 \%$ of the population uses it occasionally [8]. Digital media are the most important source of information, especially among the younger population. With the development of health-related digitization (also known as eHealth), internet-based health information and the use of mobile apps for health topics (also known as mobile health [mHealth]) have made extreme progress and replaced traditional face-to-face sources of information [9-11]. Digitization offers the opportunity to customize health promotion and prevention interventions and adapt them to the needs of individuals, for example, through personalized motivational SMS text messages or reminders. Besides 1-way communication of health information through mass media (eg, videos or e-books), digital health promotion and prevention can be realized with interaction in the form of web-based games or web-based forums. Other eHealth possibilities involve the monitoring of health data, web-based training or classes, digital consultations with health experts, or the provision of health information through (video) games, referred to as serious games [12]. At the same time, settings, for example, organizations and institutions, are facing digital transformation processes concerning structure, management, and organizational development, and new (digital) types of organizations are emerging, for example, virtual organizations [13]. In the health sector, digital transformation affects various organizations such as hospitals (Hospital 4.0) and pharmacies (web-based pharmacies) [14]. With the increased use of eHealth and mHealth apps, everyday life in general is becoming more and more digitalized, which has various effects on health. An example is the digital gaming environment, where web-based players face new health risks as well as accrue new health benefits [15]. Overall, the digitization and the large number of available digital technologies offer great potential in terms of health promotion and prevention, especially in settings.

However, there is still a lack of a clear and consensual definition for digital technologies in health promotion and prevention on the one hand [16] and a lack of a systematic description of the extent and characteristics of this research field on the other hand. Only a few reviews show the range of this topic and illustrate the urgency of scientific work on this issue $[17,18]$.

As we have stated previously, settings are an important starting point for health promotion and prevention efforts because of their huge impact on people's health [19] and they can be used for digital health promotion and prevention, but this new research field has not been systematically analyzed yet [20-23]. To effectively use the full potential of digital technologies, it is important to define the framework in which settings can be achieved, changed, and used in the field of digital health promotion and prevention [24]. Therefore, it might be helpful to analyze digital interventions in settings according to existing theoretical frameworks that are known from analog setting-based interventions, for example, the types of setting-based health 
promotion outlined by Whitelaw et al [7]. There is also an urgent need to identify which (digital) structures and factors in organizations need to be changed to achieve successful digital health promotion [5]. By defining and structuring the field of digital health promotion and prevention in settings, the quality and quantity of digital interventions can improve and increase, respectively, in the future.

\section{Objectives}

The overall objective of this scoping review is to provide an overview of the research targeting digital health promotion and primary prevention in settings. More specifically, it aims to (1) assess the range of scientific literature focusing on digital health promotion and primary prevention in settings regarding various outcomes such as applied technology, targeted setting or living environment (these terms are used synonymously), and area of health promotion and prevention and (2) identify research gaps resulting from these findings.

\section{Methods}

This paper follows the reporting guidelines of the PRISMA-ScR (Preferred Reporting Items for Systematic Reviews and Meta-Analyses extension for Scoping Reviews) checklist [25].

\section{Scoping Review Methodology}

\section{Overview}

We conducted a scoping review that aims at mapping a broad body of literature, identifying research gaps, and making recommendations for future research $[26,27]$. We followed the 6-step framework outlined by Levac et al [28], who updated and extended the initial framework developed by Arksey and O'Malley [27]. The steps are described separately in the following sections.

\section{Step 1: Identifying the Research Questions}

The research questions were developed by 2 reviewers (ALS and CG) through an iterative process that included exploratory literature searches, an exploration of relevant terms and concepts, and thematic discussions. In addition, we interviewed experts in the field of scientific reviews in public health on the thematic content, methodological approach, and research questions.

\section{Step 2: Identifying Relevant Studies}

The search strategy was developed with the support of a specialized librarian in public health. The following scientific databases were searched:

- $\quad$ MEDLINE (through PubMed)

- CINAHL (through EBSCO)

- SocINDEX (through EBSCO)

- $\quad$ PsycINFO (through EBSCO)

- $\quad$ PSYNDEX (through EBSCO)

- IEEE Xplore

- BASE

- Web of Science

Search terms were identified for the categories health promotion and prevention, living environments and settings, and technology and digital, including Medical Subject Headings terms and other index terms, as well as synonyms. Search terms were combined using the Boolean operators $O R$ and $A N D$. The search was restricted to articles published in English or German from 2010 to January 2020. To exclude reviews and web-based surveys (that do not report on a technology for health promotion or prevention) the terms NOT review and NOT online survey were used. Where possible, the database filter humans was applied. The exclusion criteria are described in detail in the next section. We also included gray literature. Therefore, we screened websites focusing on the topic of digitization and health promotion or prevention. Websites of governments, health promotion associations, medical or health-related facilities, health insurance companies, and universities and other scientific institutions were screened. The last research step included a screening of the reference lists of all eligible articles. The full search strategy, including the scientific databases and search terms, is provided in Multimedia Appendix 1.

\section{Step 3: Study Selection}

\section{Overview}

The references were independently screened by 2 reviewers (ALS and CG) for consistency with predefined inclusion and exclusion criteria, starting with screening the titles and abstracts and followed by screening the full texts. Rayyan (Qatar Computing Research Institute), a web-based application developed to facilitate the review process, was used for this step. Conflicts were discussed between the reviewers (ALS and CG) and with scientific experts according to the inclusion and exclusion criteria. The a priori-defined inclusion and exclusion criteria are described in the next sections using the Population, Concept, and Context principle [29].

\section{Concept}

The included articles had to report on interventions for health promotion or primary prevention. Primary prevention includes all those interventions that are implemented before the first occurrence of an undesirable condition. Examples are vaccinations for people who do not belong to a risk group or interventions to prevent unhealthy behavior or organizational health risks. Primary prevention must be differentiated from secondary prevention aiming at the early detection or control of diseases and from tertiary prevention targeting the chronification, consequential damage, or relapse of diseases. Methods for disease prevention could be education, normative and regulative proceedings, or economic incentive and sanction mechanisms [30]. All articles concerning secondary or tertiary prevention were excluded. For this reason, we excluded articles focusing on already present risk behaviors such as smoking cessation or weight loss for people who are overweight, as well as articles addressing screenings for early disease detection. Furthermore, a distinction can be made among universal, selective, and indicated prevention. We included universal prevention; for example, if an intervention was implemented in an entire school class with the aim of health promotion or primary prevention. We excluded selective and indicated interventions, which are defined as interventions focusing on people with risk factors or precursors of a disease [30]. We included preventive or health-promoting interventions at 
specialists' practices (eg, sexual health clinics) if the intervention was not aimed in particular at people who are already ill or those classified as at risk. Thus, it is possible that healthy people attend a preventive health screening or accompany someone who is ill. Furthermore, it is possible that the health issue that led to their appointment is separate from the primary preventive or health-promoting intervention. Besides primary prevention, articles were included if they reported on health promotion. Health promotion interventions aim at enabling the population to enhance their health by strengthening resources [19]. Interventions focus either on strengthening individuals to be empowered or on augmenting the social, ecological, and economic factors that influence people's health [31]. In this context, the concept of healthy settings has to be mentioned. According to the World Health Organization (WHO), a setting for health is a "place or social context in which people engage in daily activities in which environmental, organizational and personal factors interact to affect health and wellbeing" [4,32]. Rosenbrock [3] follows a broader approach and defines settings as a relatively permanent social context that the members have to be subjectively aware of. This includes rather informal settings such as neighborhoods or groups of people with the same value orientation or life circumstances. In our review, we want to outline the research field in its whole breadth; hence, we will refer to the broader setting definition. This means that we also include more informal settings.

In addition, the included articles had to involve up-to-date digital technologies that are used by the setting members. Digital technologies differ from analog ones in that they "operate on the basis of a discrete code. Usually this code is binary, constructed from sequences of binary digits or bits, each of which can be in one of two states, named 0 and 1" [33]. Therefore, we included web-based programs and mobile apps that are used through a computer, telephone, smartphone, tablet, or other digital devices. Games played on a gaming console were included too. Interventions using videos only were included if these were available through a mobile app (eg, tablet) or were accessible on the web. Interventions using traditional or, rather, obsolete DVDs, television, or radio were excluded.

\section{Population}

Following the definition of health promotion and primary prevention, articles were included if the intervention targeted healthy people. Therefore, articles focusing on people engaging in risky health behavior or already having symptoms or diseases were excluded.

\section{Context}

Health promotion or prevention interventions were included if they referred to a setting according to the definitions suggested by the WHO [4] and Rosenbrock [3]. Examples are formal organizations such as schools, universities, and health care facilities. Furthermore, we included less formal settings such as households and neighborhoods because they meet the criteria of a setting by featuring a social context that the setting members (eg, household members or neighbors) are aware of. Articles relating to the workplace as a setting were excluded because the field of health promotion and prevention at work is a separate specific research area within public health. The reviewers had the presupposition that the definitions and characteristics of formal and informal settings might be applicable to digital environments or a digital social context (eg, social media platforms). Therefore, the accordance of the screened articles with the definition of a setting was checked not only for analog conditions, but also for digital conditions. According to the definitions, a criterion is the existence of an accepted social system, namely a given social context that the users of the digital technology are aware of. This criterion was considered fulfilled if the digital technology allowed social interaction among different users of the technology and if the users were aware of the existence of other users. Another criterion was that the social context exists relatively permanently. This criterion was considered fulfilled if the social interaction within the digital technology was not only possible once, but also over a longer period. In accordance with the definition, the identified digital settings could be characterized as formal (such as digital organizations) or informal (such as digital groups of friends).

Besides the Population, Concept, and Context principle, another inclusion criterion concerned the publication type and study design. Nearly all publication types, empirical as well as nonempirical (eg, discussion papers), and study designs were included. The only study design excluded was reviews because the studies included in reviews would have been listed in the relevant databases and would have been identified through our search strategy if they corresponded to our inclusion criteria. In addition, we excluded abstracts and posters because they would not deliver all the required study information. Furthermore, articles had to be published in English or German from 2010 to January 2020. The time restriction was necessary because of the rapid and significant changes that occur in the digital sector.

\section{Step 4: Charting the Data}

Data extraction was conducted independently by 2 reviewers (ALS and CG). For this purpose, a data extraction form was developed, which was discussed during the expert consultations and updated during the extraction process. The reviewers extracted general publication characteristics, for example, year of publication, country, and publication type or study design on the one hand, as well as specific outcomes that are relevant for the description and mapping of the research field, for example, the type of applied technology, the type of setting, the target group of the intervention, and the area and method of health promotion or prevention on the other hand.

The distinction according to the technology type was made based on the study by O'Neil et al [34], which included mobile devices (eg, smartphones and tablets), computer- and web-based programs, social media apps, and telemonitoring devices. We added gaming consoles to the classification. The method of health promotion and prevention was determined according to the distinction by Leppin [30]. The author first distinguishes whether the behavior or the environment is being changed. Second, the author differentiates among educational interventions (including information provision and training), normative and regulative proceedings (eg, new laws or prohibitions), and economic incentive and sanction mechanisms. To this categorization, Scherenberg [12] adds methods for digital 
health prevention, including monitoring, reminder, social interaction, and social support (eg, digital challenges or encouragement).

\section{Step 5: Collating, Summarizing, and Reporting the Results}

Following Levac et al [28], this stage was divided into 3 distinct steps. First, we analyzed the results, including numerical summary analysis. Second, we reported the results focusing on the outcomes that referred to the overall research aims. Third, we considered and discussed the findings and their meaning for future research, practice, and policy. We did not carry out a critical appraisal of the methodological quality of the included articles because the aim of this scoping review is to provide an overview of the research field and not to analyze the effectiveness of interventions.

\section{Step 6: Consultation}

As mentioned previously, the review process was supported by scientific experts through regular consultations and discussions. The scientific advisory board included a specialized librarian, an expert in conducting literature reviews, and an expert in the field of digital health promotion and prevention.

\section{Results}

\section{Overview}

The initial database search resulted in the identification of 8847 records, and the gray literature search resulted in the identification of 41 records. From the 8888 articles, 1500 $(16.88 \%)$ duplicates were removed, leaving 7388 (83.12\%) articles eligible for screening by title and abstract. Of these 7388 articles, $6794(91.96 \%)$ were excluded after the screening, leaving 594 (8.04\%) articles for the full-text appraisal. Of these 594 articles, after the full-text appraisal, a further $424(71.4 \%)$ were excluded, leaving $170(28.6 \%)$ articles that met the inclusion criteria. In addition, the reference lists of these articles were screened, which led to a further 30 articles being identified; therefore, the literature search yielded 200 articles. The whole review process is summarized in the PRISMA (Preferred Reporting Items for Systematic Reviews and Meta-Analyses) flowchart [35] in Figure 1.

Figure 1. PRISMA (Preferred Reporting Items for Systematic Reviews and Meta-Analyses) flowchart.

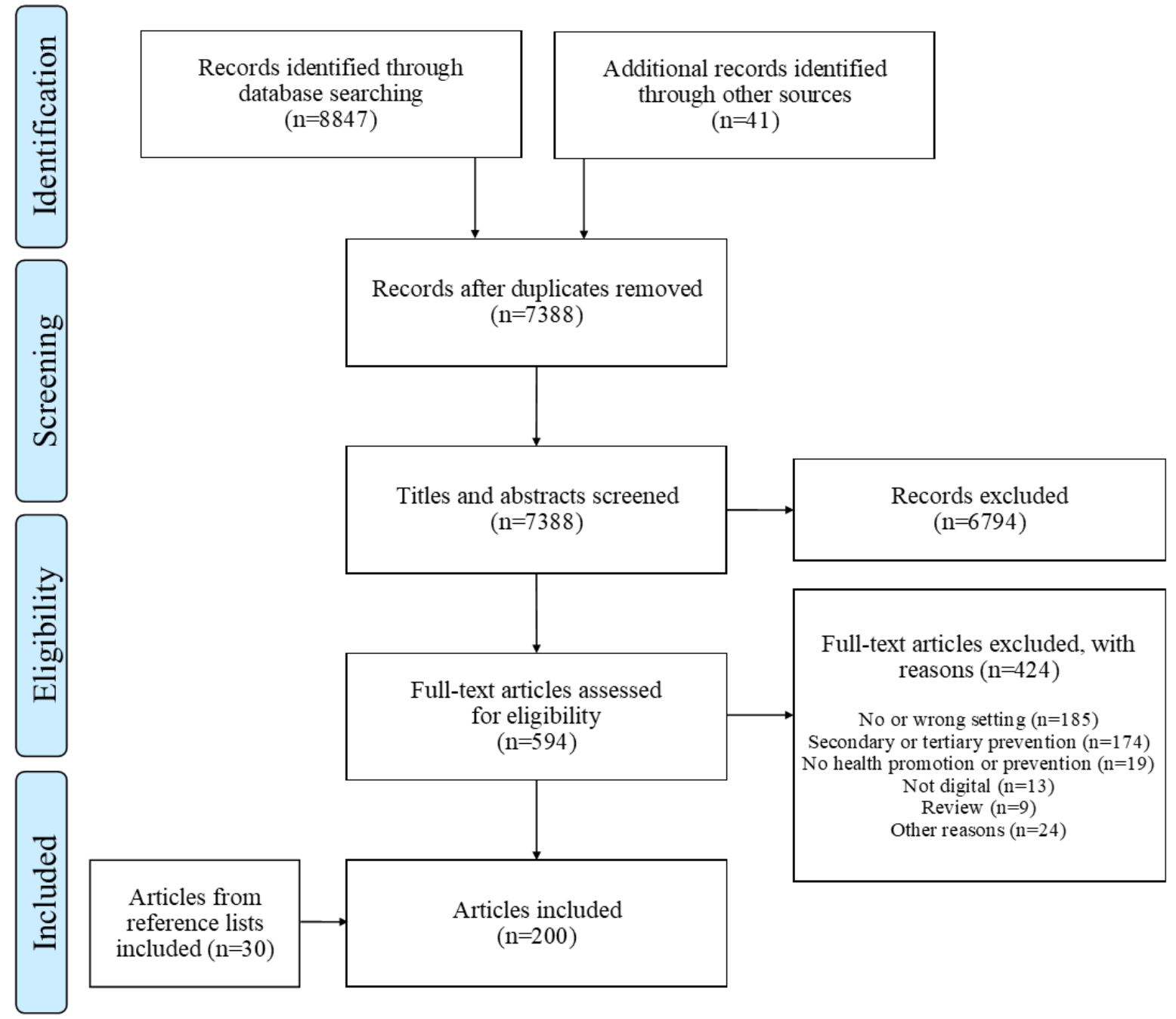




\section{General Characteristics of the Publications}

The articles included in this review were published from 2010 to January 2020. There were 9-28 publications per year in the research area of digital health promotion and prevention in settings (except for 2020 where the search was restricted to January of that year). Whereas the number of publications was 9 and 10 in 2010 and 2011, respectively, it doubled in 2012 and thereafter fluctuated from 16 to 28 publications, with the peak in 2016 and the minimum in 2017. The data extraction chart, including all extracted data used in this review, is provided in Multimedia Appendix 2 [36-235].

In total, we found publications from 25 different countries on 6 continents (based on the country where the first author's research institution is based). Of the 200 articles, 94 (47\%) were published in the United States and $3(1.5 \%)$ in Canada, whereas $96(48 \%)$ were published in Europe. Of these 96 articles, 15 $(16 \%)$ originated from Germany, $12(13 \%)$ from the Netherlands, 11 (11\%) from the United Kingdom, and $6(6 \%)$ from Belgium, whereas other European countries, including Italy, Norway, Denmark, Portugal, Austria, Finland, Ireland,
Sweden, Switzerland, Spain, and Greece, each accounted for 5 (5\%) or fewer publications. Of the 200 articles, 21 (10.5\%) were from Australia, whereas Asian countries, including India, Thailand, Taiwan, Korea, and China, each accounted for 3 $(1.5 \%)$ or fewer publications; 2 (1\%) articles originated from South America (Brazil), and $1(0.5 \%)$ was published in an African country (Uganda).

Of the 200 articles, 178 (89\%) were empirical studies. Most of these 178 studies had a quantitative study design: 65 (36.5\%) were randomized controlled trials (RCTs), 22 (12.4\%) were cross-sectional studies, 15 (8.4\%) were pretest-posttest studies, $13(7.3 \%)$ were secondary data analyses, $11(6.2 \%)$ were study protocols, and $7(3.9 \%)$ were controlled trials. Of the 178 empirical studies, a further $27(15.2 \%)$ followed a mixed methods approach. Of these 27 studies, 4 (15\%) were study protocols and $1(4 \%)$ was a secondary data analysis. Of the 178 studies, $18(10 \%)$ had a qualitative design. In addition, among the 200 studies, we found $22(11 \%)$ nonempirical publications, including theoretical or discussion papers, technology or framework descriptions, and thematic overviews. Figure 2 shows the distribution of study designs by publication year.

Figure 2. Study designs by publication year $(\mathrm{n}=200)$.

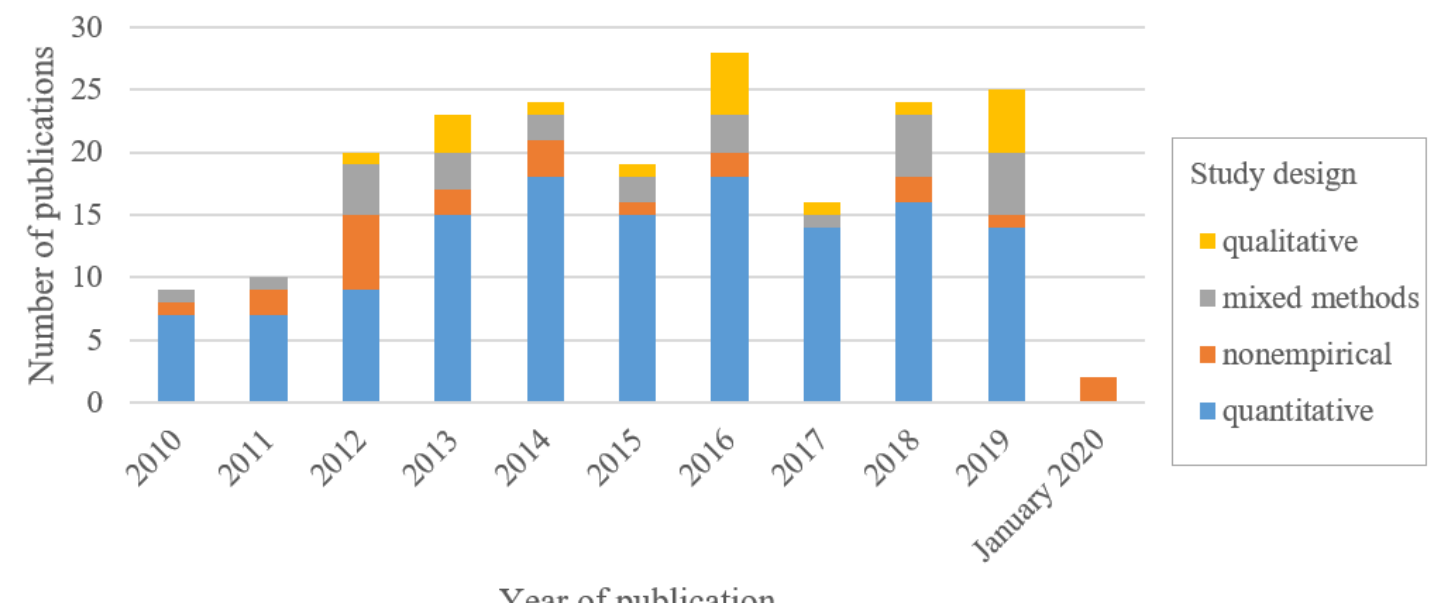

Year of publication

\section{Type of Digital Technology Used for Heath Promotion and Prevention in Settings}

As Figure 3 shows, the type of digital technology used for health promotion or prevention can be distributed through mobile devices (eg, smartphones and tablets), computer- and web-based programs, social media apps, telemonitoring devices (eg, external sensors or smartwatches), and gaming consoles. Of the 200 studies, $126(63 \%)$ targeted computer- and web-based programs, $39(19.5 \%)$ a mobile device, and $38(19 \%)$ a social media app, whereas only a small number $(6 / 200,3 \%$, or fewer $)$ reported on one of the other technology types. As some publications reported on $\geq 1$ technology types, the sum of the percentages adds up to $>100 \%$ in $>200$ articles (this also applies to the targeted areas and methods of health promotion and prevention, described in the Areas and Methods of Digital Health Promotion and Prevention in Settings section). 
Figure 3. Types of digital technologies ( $\mathrm{n}=213$ due to the fact that some publications report on more than one technology type).

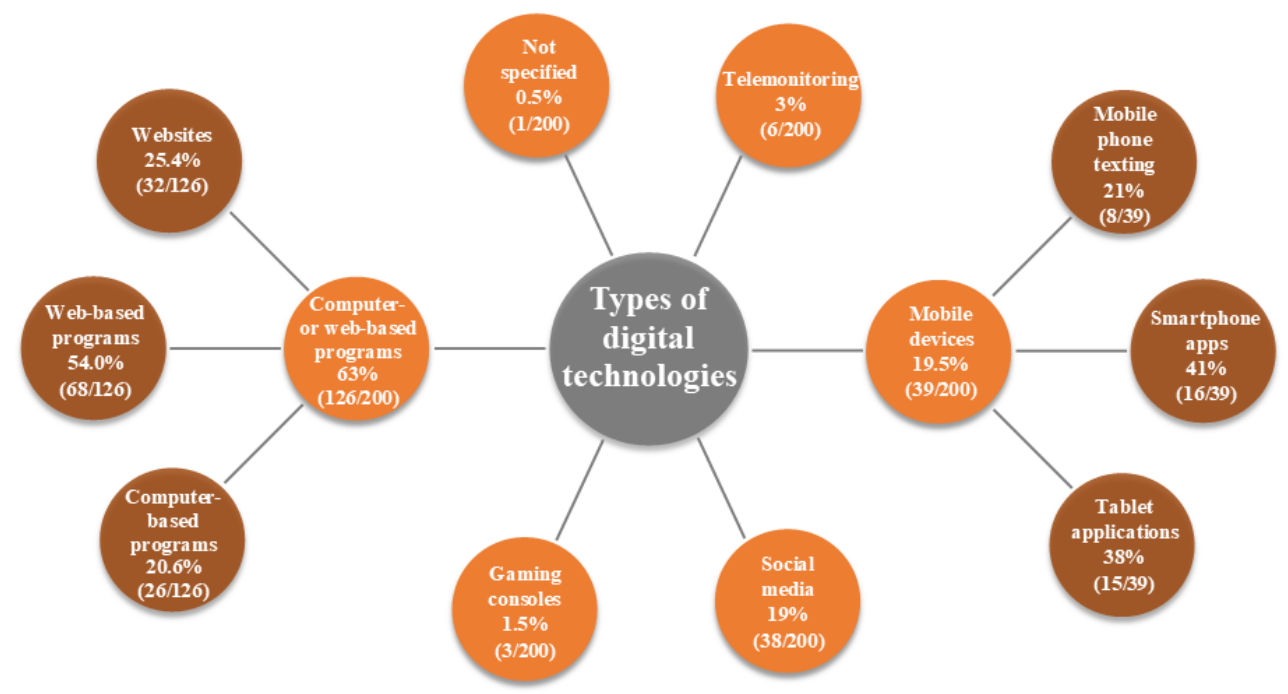

Furthermore, these technology types offer different apps that are used for health promotion or prevention purposes. Regarding the technology type mobile devices, $41 \%$ (16/39) of the publications reported on smartphone apps and 38\% (15/39) reported on tablet apps, whereas $21 \%$ (8/39) used mobile phone texting. Of the interventions that included a computer- or web-based program, $54.0 \%$ (68/126) were web-based programs, $25.4 \%(32 / 126)$ were websites, and $20.6 \%$ (26/126) were computer-based programs.

There were different apps and programs with a variety of digital functions and options for users mentioned in the publications, which cannot be described in detail in this review. A few apps are presented as examples here. An example is the use of a smartphone with an integrated geographic information system for the promotion of physical activity. The underlying idea is that specific environmental conditions of a neighborhood can promote physical activity. These features, referred to as neighborhood walkability, can be measured through a geographic information system and used to improve the environmental conditions [36]. Other interventions used computer-based programs, including virtual reality, for health promotion and prevention purposes. As an example, a study combined stationary cycling at independent living facilities for older adults with virtual reality to create a computer-simulated environment (cybercycling). This intervention, also referred to as an exergame (a digital game that requires one to perform physical exercise), aims at improving the cognitive function of older adults [37]. Another digital intervention concerns serious games, which are digital games with educational objectives played on computers or mobile devices. We identified serious games for various health promotion and prevention purposes, for example, a game tackling childhood obesity in schools [38] or a game on neglected tropical diseases developed for use in a community [39]. As an example for telemonitoring devices, a study focused on the real-time monitoring of children's physical activity in school measured by smartwatches and supervised by classroom teachers, which, over the course of time, enables teacher-regulated strategies for providing more opportunities for physical activity [40]. A gaming console was used, for example, by children in schools, where active video games were played to enhance their physical activity during school breaks [41]. Another intervention at a preschool investigated the use of a social media platform for the delivery of health-related education materials to augment a classroom-based obesity-prevention curriculum [42].

\section{Target Groups and Targeted Settings in Digital Health Promotion and Prevention}

The analysis identified 2 categories of target groups for digital health promotion and prevention interventions. First, there were interventions where the users of the technology were the direct target group for health promotion or prevention. Examples of direct target groups were adolescents, adults, children, church members, community members, expatriates or travelers, men, mothers or pregnant women, older adults, patients, school or university students, vacationers, women, and young adults. In addition, some publications focused on people from a specific cultural, linguistic, or sexual background (eg, refugees, bisexual men, and people living in rural areas). Others had $>1$ target group or did not specify the target group. Of the 200 included studies, most $(48 / 200,24 \%)$ targeted school students, followed by those targeting older adults $(18 / 200,9 \%)$, university students $(17 / 200,8.5 \%)$, and adults in general $(15 / 200,7.5 \%)$. Second, there were interventions where the technology users were not the direct target group for health promotion or prevention. Instead, the technology users (as multiplicators or mediators) were empowered or supported through the use of the technology to ensure that other people received health promotion or prevention. Examples of multiplicators or mediators were parents, teachers, doctors, and childcare center directors.

The aforementioned target groups already indicate some settings where digital health promotion and prevention interventions take place. The settings were divided into formal and informal settings. The formal analog settings that we identified were schools, universities, and other educational settings; community facilities (eg, churches or prisons); health care facilities (eg, primary care, dental, sexual health, or vaccine clinics); and care for older adults or childcare facilities. Informal analog settings were communities or neighborhoods and the household or home. We identified several digital technologies that might be 
characterized as a digital setting at the time of publication. These were web-based distance learning universities; virtual reality apps; and social media, including apps, websites, and web-based platforms or web-based programs that offered discussion boards, forums, or other ways of social interaction. The web-based distance learning setting can be characterized as a formal digital setting.

Overall, with $31.5 \%(63 / 200)$ of the publications reporting on it, social media was the most frequent setting in digital health promotion and prevention. Another 19.5\% (39/200) of the publications reported on schools as a setting, 12\% (24/200) on neighborhoods or communities, and $6.5 \%(13 / 200)$ on health care facilities. Furthermore, 6\% (12/200) focused on the informal setting household or home and 3\% (6/200) on the formal setting universities. Other publications thematized interventions that used combinations of analog and digital settings that we refer to as blended settings. For instance, interventions in the community were often complemented with a digital app that itself represented a digital setting (eg, a social media platform). The same combinations were found for schools and universities.

\section{Areas and Methods of Digital Health Promotion and Prevention in Settings}

The included articles dealt with different areas of health promotion and prevention. Physical activity interventions were the most commonly applied, with $40.5 \%$ (81/200) of the publications thematizing them. Other often considered areas were nutrition in $22.5 \%(45 / 200)$ of the publications; sexual health in $17 \%$ (34/200); substance use, for example, alcohol or drug use, in $10 \%$ (20/200); weight in 9.5\% (19/200); and mental health in $5.5 \%(11 / 200)$. Only a few publications described interventions for health promotion or well-being in general $(9 / 200,4.5 \%)$, for vaccination $(8 / 200,4 \%)$, and for various risk factors at once $(10 / 200,5 \%)$. Other health topics that were tackled rarely were bone and oral health, sound and sun exposure, cognitive function, fall prevention, sleep, and transmission of diseases (17/200, 8.5\%; Multimedia Appendix 3).

Besides the areas of health promotion and prevention, we analyzed the methods used to achieve health promotion and prevention among the target group. Most of the publications reported on interventions that combined several of the following methods: environmental change; providing information, social support, training, or incentives; and monitoring. The provision of information was the most used method (181/200, 90.5\%). It aimed at improving the knowledge of the target group regarding a specific health promotion or prevention topic and thereby changing health behavior. Of the 200 interventions, 79 (39.5\%) offered some form of social support, for example, through connecting people with the same health problem or the same health goals to motivate the target group. Approximately every fifth intervention $(41 / 200,20.5 \%)$ used monitoring as a method for health promotion and prevention. By giving users the opportunity to collect, visualize, and control health-related data over a longer period, monitoring enabled the user to recognize progress and stay on track. Of the 200 articles, 30 (15\%) aimed at changing environmental conditions, for example, a change in the supermarket environment [43] or the school environment [44]. Only a few interventions used incentives as a mechanism to influence health behavior $(8 / 200,4 \%)$ or provide physical or mental training $(19 / 200,9.5 \%)$.

The different methods of health promotion and prevention indicate that one should further distinguish between structural and behavioral health promotion and prevention in settings. Structural health promotion and prevention is realized by changing setting-based or organizational structures. Only a small percentage $(30 / 200,15 \%)$ of the identified articles dealt with structural health prevention. Of these 30 articles, 24 (80\%) focused on environmental or organizational changes in analog settings such as neighborhoods, supermarkets, schools, childcare centers, and home environments. An example is a smartphone app that enabled community members to document neighborhood features through geocoded photographs. The intervention aimed at identifying and changing aspects of the physical and social environment that influenced the health behavior of the community members [45]. Only a few articles $(6 / 30,20 \%)$ discussed structural changes in digital settings, for example, social networking sites.

Behavioral health promotion and prevention interventions were used in $85 \%(170 / 200)$ of the included articles. In these behavioral interventions, the setting served as a place to reach a specific target group and offer them an intervention for changing their health behavior. The provision of a tablet in the waiting room of a sexual health clinic that provided access to a website with information for safer sex aiming at a change in sexual behavior is an example [46].

\section{Discussion}

\section{Principal Findings}

Our results provide an initial basis for finding a consensus on the terminology of digital health promotion and prevention in settings through further research. The overall objective of this scoping review is to provide an overview of research targeting digital health promotion and primary prevention in settings. It focuses on assessing the range of scientific literature regarding various outcomes such as applied technology, targeted setting, and area of health promotion or prevention as well as on identifying research gaps that result from these findings. The results provide a first overview of scientific research on digital health promotion and prevention in settings. We have shown the wide range of applications of digital technologies in settings and identified research gaps. We systematically searched for empirical and nonempirical publications from 2010 to January 2020 and identified 200 references that met our inclusion criteria. The data analysis showed that there is a broad range and diversity of literature on digital health promotion and primary prevention in settings regarding various outcomes. Thus, we found publications focusing on a large spectrum of target groups, settings, and technologies as well as areas and methods of health promotion and prevention.

We discovered a wide range of analog, digital, and blended settings where digital health promotion and prevention interventions were applied. Regarding our results, it must be 
considered that there is a scientific discourse about the definition and application of the concept settings for health promotion and prevention. Whereas some researchers support a broader approach, others recommend a narrower definition that only focuses on formal organizations [1]. As we have stated previously, we chose the broader approach.

To our knowledge, this is the first review focusing on digital health promotion and prevention in settings; therefore, we have to consider other studies and sensibly embed and discuss their results compared with our findings. Looking at digital interventions in the field of health promotion and prevention in general, one can see that settings are rarely taken into account. Thus, Norman et al [236] found in their systematic review that eHealth interventions for physical activity and nutrition were sometimes implemented in analog settings such as communities, schools, primary care, or workplaces. In addition, Bailey et al [237] identified in a scoping review that digital interventions for sexual health promotion were delivered in various analog settings, including schools, universities, and health care facilities; through web-based conditions; or through a combination of both, which supported the results of our scoping review.

There is a lack of a (uniform) definition of the terms digital setting and blended setting; therefore, a way has to be devised to bring together previous knowledge in this area and our results. In line with our presuppositions and results, Loss et al [47] concluded that social networking sites might be categorized as a setting for health promotion and prevention. Other than this publication, the existing scientific literature lacks an extensive and in-depth discussion about the existence and forms of digital (and blended) settings. What can be stated is that the most commonly found digital setting in this review, namely social media, is a widely discussed and used platform for health promotion and prevention interventions in terms of behavioral interventions. It is considered that social media interventions have the potential to facilitate access to health information as well as to expand the reach, improve the efficacy, and lower the costs of health promotion and prevention interventions [238-241]. However, it must be taken into account that the perspective of organizations (besides the workplace) has so far been largely absent from the scientific literature. The digitization of a formal organization in the field of health promotion and prevention is accompanied by massive structural changes. So far, however, these have not been scientifically investigated and evaluated - apart from digital health promotion in the workplace. For future research in the field of digital setting-based health promotion and prevention, this perspective must be taken into account.

What is most striking is the wide range of technologies used to implement health promotion and prevention in settings. These range from simple SMS text messages and smartphone apps to web-based programs offered on tablets in the waiting areas of health care providers. The existence of so many different technologies in the field of health promotion and prevention was identified in other reviews as well [34,242]. This diversity results from the rapid development of technologies in the health sector in the last few years, and it is reflected in the variety of terms that exist to define digitization in the health sector, for example, digital health, eHealth, mHealth, and Health 2.0. [16]. Another reasonable distinction of technology types comes from Lupton [238], who differentiates health promotion and prevention technologies between Web 1.0 and Web 2.0 applications. Web 2.0 refers to a newer generation of web-based applications that enable interaction and that allow users to generate, create, and share information [48]. This distinction can also be applied to the articles we identified.

Another central finding refers to the distinction between structural and behavioral health promotion and prevention in settings. Thus, most $(170 / 200,85 \%)$ of the publications on digital health promotion and prevention in settings can be categorized as behavioral health promotion and prevention in settings. In many cases, this means that the setting was used to reach a specific target group aiming at a change in their behavior. Consequently, we found a lack of articles concerning structural health promotion and prevention in settings, specifically a lack of interventions aiming at a change in setting-based and often organizational structures. It remains unclear how structural changes in settings can be achieved using digital interventions. Among the publications that were oriented toward structural health promotion and prevention in settings, only a few discussed structural changes in digital settings compared with changes in analog settings. This highlights that besides the lack of a scientific discussion on the existence and forms of digital settings for health promotion and prevention (which we have already pointed out), there is a research desideratum on how the structures of digital settings can be changed to improve the health of digital technology users.

Following the categorization of setting-based health promotion by Whitelaw et al [7], most of the digital health-promoting interventions can be classified under passive model where the setting is used as an access to individuals to try to get them to change their behavior. Interventions mostly miss out on taking into account the specific structures, social contexts, and interaction possibilities of the setting and cannot therefore be assigned to the other models. Nevertheless, we found a few examples in the literature where the digital setting-based intervention includes characteristics of the other intervention types. Table 1 presents examples of identified studies that were assigned to the types described by Whitelaw et al [7]. This overview demonstrates that existing theoretical frameworks from analog interventions can be used to structure digital health-promoting and preventive interventions in settings. Further research should focus on whether new types of setting-based health promotion emerge as a result of digitization. 
Table 1. Digital interventions and types of setting-based health promotion (types based on Whitelaw et al [7], following Engelmann and Halkow [1]).

\begin{tabular}{ll}
\hline Type & Example of digital health promotion or prevention
\end{tabular}

\section{Passive model}

- Individuals and their health-relevant behavior are at the center of interventions

- $\quad$ Setting is used as an access to individuals and groups to provide them with the health-promoting intervention

- Health promotion in the setting

\section{Active model}

- $\quad$ Focuses on the health behavior of individuals

- Some behavior changes are inhibited or enabled by structural features of the setting

- $\quad$ Structural modifications are required

\section{Vehicle model}

- Focuses on individual health issues

- Projects are intended to initiate systemic changes

- $\quad$ Projects serve as door openers for developments at other levels of the setting

- The focus is on structural factors and their influence on health, even if individual health issues are addressed first

\section{Organic model}

- Social systems are the product of the processes of individuals and groups living and acting together

- Interventions bring systemic changes that affect the communication culture and community values in the setting

- The setting is understood as the shaping framework for health, which is also shaped by setting members

- Participation and empowerment of people to shape their environment are key concepts

\section{Comprehensive model}

- Health is shaped by setting influences

- $\quad$ Settings are understood as superordinate systems in which the individual has hardly any possibilities to shape them himself

- Interventions are often implemented from the top down by the setting policy

\section{Bailey et al [46]}

- The intervention consisted of a tablet that was displayed in a waiting room showing a website that aims to increase condom use and reduce sexually transmitted infections

- $\quad$ The setting health clinic was used to access individuals to try to get them to change their health behavior

- $\quad$ Setting or organizational structures were not considered

\section{Bourdeaudhuij et al [49]}

- An internet-based physical activity intervention was implemented in schools

- The aim of the intervention was to change health behavior

- A few structural features of the setting were considered, for example, technical equipment or environmental barriers

Templeton et al [50]

- The aim was to create a web-based sexual health-promotion intervention to encourage young men in prisons to avail of regular sexual health checkups

- The health intervention was used to achieve overarching goals, for example, to initiate collaborative partnerships to disrupt structures that lead to health inequities, to fulfill the human rights of prisoners, to develop a health-promoting prison

Sheats et al [43]

- Citizens use an app to collect data about their neighborhood that facilitate or hinder healthy living

- They use the findings to advocate for change in partnership with local decision-makers and policy makers

- Includes community-engaged methods to empower citizens

- This transforms the possibilities of participation and communication in the community

Delany et al [51]

- Web-based canteen ordering system in a school is altered with the methods of labeling, placement, and prompting to achieve healthier food choices of students

- Change in the ordering system as a political decision of the school

- Intervention is implemented from the top down; decision is not up to the students
We identified a wide spectrum of methods that are applied to achieve health promotion or prevention through digital interventions. It is noticeable that the methods of training and monitoring are mostly used for interventions on physical activity, whereas environmental change was mostly applied as a method within interventions on nutrition. A reason for that could be that there exist monitoring devices that are more effective or easier to use in the area of physical activity, for example, pedometers that automatically count steps compared with devices that monitor food intake. In addition, it is possible that environmental changes are easier implemented or more effective in the area of nutrition, for example, changes in the food environment at home compared with changes in physical activity options in settings. Comparing the methods used in the articles included in this review with those identified by Leppin [30] and Scherenberg [12], it is noticeable that normative and regulative proceedings as well as digital reminders were not applied. This could be because the development and introduction of new laws is difficult to realize through digital interventions and because digital reminders (eg, for vaccinations) are a method for individual health promotion rather than for setting-based interventions.

As we did not analyze the effectiveness of digital health promotion and prevention interventions in settings, this needs to be investigated in future research.

We found that most of the publications were empirical and the most used study design was an RCT. Only a small percentage had a qualitative design. Taking a closer look at the study designs, one can see that only a few studies followed a participatory design and that the RCTs usually analyzed the effectiveness of behavior-changing interventions. Therefore, one could conclude that research on digital health promotion and prevention in settings is at an advanced stage because digital apps are tested on their effectiveness rather than being in a previous stage of developing technologies or more fundamental 
research. However, as we did not find many articles focusing on structural health promotion and prevention in settings, we cannot generalize this interpretation to the whole research field. As we have stated previously, there is a huge research gap concerning structural health promotion and prevention in settings, and research that is more fundamental is needed in this area. A possible explanation for the huge number of RCTs regarding behavioral health promotion and prevention and the lack of RCTs regarding structural health promotion and prevention could be that the effectiveness of changing health behavior (eg, physical activity) is more easily measurable than the effectiveness of changing structures or processes in formal and informal settings.

\section{Limitations}

This scoping review was conducted in compliance with the standards of the methodological approach outlined by Levac et al [28] and in accordance with the reporting guidelines of the PRISMA-ScR checklist [25]. Nevertheless, it includes some limitations that have to be taken into account.

First, the database search was very challenging because it was difficult to find suitable keywords that reflect the concept of a setting so as to be understood in the field of health promotion and prevention. Especially in combination with the term technology, the meaning of the word setting was not equivalent to our understanding of the concept. In addition, in none of the databases was the term setting well indexed. Another limitation derives from the fact that we searched for the terms health promotion and health prevention in general. We did not expand our search to specific health promotion areas such as physical activity or mental health. Therefore, we might have missed some articles if the terms health promotion or health prevention were not listed.

Second, our analysis and results are based on our presupposition that the definition of a setting for health promotion and prevention is applicable in the digital context too. Because of a lack of a definition of the term digital setting, the inclusion and exclusion criteria are based on the definitions of the term setting provided by Rosenbrock [3] and the WHO [4]. This presupposition has to be confirmed in the future to verify our results.

Third, we limited our search to the area of primary prevention and to health promotion and prevention in settings other than the workplace. These restrictions were chosen because of the huge breadth and diversity of the research area. It is possible that the inclusion of articles on secondary and tertiary prevention as well as articles regarding the workplace would have produced different results. In particular, more research has been conducted on digital health promotion in the workplace, and methods and technologies could potentially be applied to settings outside of the workplace.

\section{Recommendations for Future Research}

As we have stated previously, there are major research gaps in the research area of digital health promotion and prevention in settings, and there is a lack of a sufficient consideration of settings in the field of digital health. In future, the setting approach ought to be given greater importance, especially in the research area of digital health and digital health promotion and prevention. This includes developing definitions for the terms digital setting and blended setting and specifying their fields of application and the different forms that exist. In addition, key features of digital and blended settings have to be explored, especially with regard to their health impact. We currently know far too little about what elements define a digital setting. We need to further investigate the relevance of social interaction for the definition of digital settings.

Especially, there is a lack of research on structural health promotion and prevention in settings. As described previously, more research is needed on how digital technologies can change structures of formal and informal settings and how structures of digital settings themselves can be changed. Future research should focus on how structural change can be applied (eg, through organizational development), how it can be measured, and what stakeholders (eg, leaders or members of an organization) should be involved in this process. Therefore, a more detailed analysis of the identified articles on structural health promotion and prevention in settings seems useful.

It would also be desirable for future research to consider the development of digital health-promoting tools that focus on all target groups in a setting and that consequently consider the organization as a holistic setting with the different needs and requirements of the various target groups and thus do justice to the complexity and multidimensionality of the setting.

In our scoping review, we successfully mapped the research field of digital health promotion and prevention in settings regarding various outcomes. What remains unclear is the effectiveness of these interventions. Future scientific research should also examine the effects of digital interventions, especially the long-term effects. Digital health promotion and prevention technology can only establish itself when the benefits and risks for a population are proven. In addition, more participatory research is needed to ensure that the needs, wishes, (digital) competences, and possible fears of users are considered in the development, testing, and implementation of these technologies. It would also be interesting to see to what extent participatory research can take place in digital settings or to what extent the WHO's healthy setting principles (including community participation, partnership, empowerment, and equity [243]) can be achieved through digital tools. Such research would contribute to the acceptance and eventually to the extensive use of digital technologies for health promotion and prevention.

\section{Conclusions}

Our review provides an overview of the research on digital health promotion and prevention in settings. We demonstrated that the research field is complex, heterogeneous, and broad, and our findings reveal research gaps that urgently need to be addressed. A gap concerns study on structural health promotion and prevention in settings, and another concerns the definition of relevant terms, for example, digital settings. As the topic of digitization in setting-based health promotion and prevention is multidisciplinary, covering disciplines such as public health, organizational development, and the technology industry, in our opinion, the most important aspect is that different 
disciplines combine their expertise and work collaboratively to bridge these research gaps. In this context, the participation of potential technology users is unavoidable to guarantee that the users' needs, especially the needs of the vulnerable, are considered. In addition, it is urgently necessary to clarify which significant improvements will result from the application of digital technologies. So far, there is insufficient basic research that provides information about which technologies in which health areas are best suited to certain settings or target groups. Therefore, in future studies, the great potential of digitization should be further explored based on validated scientific research. Especially, the benefits for the populations' health and the possibility of making health promotion and prevention interventions more effective and less expensive need to be analyzed.

\section{Acknowledgments}

The authors would like to thank the members of the scientific advisory board, Professor Dr Ralph Möhler (Bielefeld University), Professor Dr Kevin Dadaczynski (Fulda University of Applied Sciences), and Birgit Hollmann (Bielefeld University), who supported the review process through regular consultations and discussions. This scoping review was funded by the German private health insurance association, Verband der Privaten Krankenversicherung e.V., as part of a research project. The review was conducted independently by a research team at the University of Bielefeld. The authors would also like to acknowledge support for the article processing charge by the Deutsche Forschungsgemeinschaft and the Open Access Publication Fund of Bielefeld University.

\section{Authors' Contributions}

ALS and CG led the literature review and the research process, led critical reflections on the analysis and the concept, and prepared the manuscript, which was critically reviewed and revised by all authors. CD supervised the research, supported the writing process, and provided critical input. All authors have read and approved the final manuscript.

\section{Conflicts of Interest}

None declared.

\section{Multimedia Appendix 1}

Search strategy.

[PDF File (Adobe PDF File), 121 KB-Multimedia Appendix 1]

\section{Multimedia Appendix 2}

Data extraction chart.

[PDF File (Adobe PDF File), 208 KB-Multimedia Appendix 2]

\section{Multimedia Appendix 3}

Areas of health promotion and prevention $(n=254$ due to the fact that some publications report on more than one area). [PNG File, $57 \mathrm{~KB}$-Multimedia Appendix 3]

\section{References}

1. Engelmann F, Halkow A. Der Setting-Ansatz in der Gesundheitsförderung: Genealogie, Konzeption, Praxis, Evidenzbasierung. Social Science Open Access Repository (SSOAR). 2008. URL: https://nbn-resolving.org/urn:nbn:de:0168-ssoar-294064 [accessed 2021-10-15]

2. Dadaczynski K, Baumgarten K, Hartmann T. Settingbasierte Gesundheitsförderung und Prävention. Präv Gesundheitsf 2016 Oct 7;11(4):214-221. [doi: 10.1007/s11553-016-0562-1]

3. Rosenbrock R. Prävention in Lebenswelten - der Setting-Ansatz. Z Allg Med 2015;91(5):213-219 [FREE Full text]

4. Health Promotion Glossary. World Health Organization. 1998. URL: https://www.who.int/healthpromotion/about/ HPR\%20Glossary\%201998.pdf [accessed 2021-12-23]

5. Batras D, Duff C, Smith BJ. Organizational change theory: implications for health promotion practice. Health Promot Int 2016 Mar 14;31(1):231-241. [doi: 10.1093/heapro/dau098] [Medline: 25398838]

6. Seibt AC. Erklärungs- und Veränderungsmodelle II: Stufen und Phasen von Planungs- und Veränderungsprozessen. In: Blümel S, Franzkowiak P, Kaba-Schönstein L, editors. Leitbegriffe der Gesundheitsförderung und Prävention: Glossar zu Konzepten, Strategien und Methoden. Köln: Bundeszentrale für gesundheitliche Aufklärung; 2011:87-99.

7. Whitelaw S, Baxendale A, Bryce C, MacHardy L, Young I, Witney E. 'Settings' based health promotion: a review. Health Promot Int 2001 Dec;16(4):339-353. [doi: 10.1093/heapro/16.4.339] [Medline: 11733453 ]

8. Frees B, Koch W. ARD/ZDF-Onlinestudie 2018: Zuwachs bei medialer Internetnutzung und Kommunikation. Media Perspektiven 2018;9:398-413 [FREE Full text] 
9. Baumann E, Czerwinski F. Erst mal Doktor Google fragen? Nutzung neuer Medien zur Information und zum Austausch über Gesundheitsthemen. In: Böcken J, Braun B, Meierjürgen R, editors. Gesundheitsmonitor 2015: Bürgerorientierung im Gesundheitswesen. Kooperationsprojekt der Bertelsmann Stiftung und der BARMER GEK. Gütersloh: Verlag Bertelsmann Stiftung; 2015:57-79.

10. Baumann E, Link E. Onlinebasierte Gesundheitskommunikation: Nutzung und Austausch von Gesundheitsinformationen über das Internet. In: Fischer F, Krämer A, editors. eHealth in Deutschland. Anforderungen und Potenziale innovativer Versorgungsstrukturen. Berlin, Heidelberg: Springer Vieweg; 2016:385-406.

11. Rossmann C, Stehr P. Gesundheitskommunikation im Internet. In: Schweiger W, Beck K, editors. Handbuch Online-Kommunikation. Wiesbaden: Springer VS; 2019:393-419.

12. Scherenberg V. Prävention Gesundheitsförderung in und mit digitalen Medien. In: Dockweiler C, Fischer F, editors. ePublic Health. Bern: Hogrefe; 2019:121-136.

13. Reinhardt K. Digitale Transformation der Organisation. Wiesbaden: Springer Fachmedien Wiesbaden; 2020.

14. Matusiewicz D, Pittelkau C, Elmer A, Addam M. Die digitale Transformation im Gesundheitswesen: Transformation, Innovation, Disruption. Berlin: Medizinisch Wissenschaftliche Verlagsgesellschaft; 2017.

15. Schott G, Hodgetts D. Health and digital gaming: the benefits of a community of practice. J Health Psychol 2006 Mar;11(2):309-316. [doi: 10.1177/1359105306061189] [Medline: 16464927]

16. Zeeb H, Pigeot I, Schüz B, Leibniz-WissenschaftsCampus Digital Public Health Bremen. [Digital public health-an overview]. Bundesgesundheitsblatt Gesundheitsforschung Gesundheitsschutz 2020 Feb 09;63(2):137-144. [doi: 10.1007/s00103-019-03078-7] [Medline: 31919531]

17. Oh H, Rizo C, Enkin M, Jadad A. What is eHealth (3): a systematic review of published definitions. J Med Internet Res 2005 Feb;7(1):e1 [FREE Full text] [doi: 10.2196/jmir.7.1.e1] [Medline: 15829471]

18. Nievas Soriano BJ, Duarte S, Alonso A, Perales A, Carreño T. eHealth: advantages, disadvantages and guiding principles for the future. JMIR Preprints 2019:23. [doi: 10.2196/preprints.15366]

19. Ottawa Charter for Health Promotion. World Health Organization. 1986. URL: https://www.euro.who.int/ data/assets/ pdf_file/0004/129532/Ottawa_Charter.pdf [accessed 2020-05-07]

20. Nittas V, Lun P, Ehrler F, Puhan MA, Mütsch M. Electronic Patient-Generated Health Data to Facilitate Disease Prevention and Health Promotion: Scoping Review. J Med Internet Res 2019 Oct 14;21(10):e13320 [FREE Full text] [doi: 10.2196/13320] [Medline: 31613225]

21. Alcântara CMD, Silva ANS, Pinheiro PNDC, Queiroz MVO. Digital technologies for promotion of healthy eating habits in teenagers. Rev Bras Enferm 2019 Apr;72(2):513-520 [FREE Full text] [doi: 10.1590/0034-7167-2018-0352] [Medline: 31017217]

22. Naslund JA, Aschbrenner KA, Araya R, Marsch LA, Unützer J, Patel V, et al. Digital technology for treating and preventing mental disorders in low-income and middle-income countries: a narrative review of the literature. Lancet Psychiatry 2017 Jun;4(6):486-500 [FREE Full text] [doi: 10.1016/S2215-0366(17)30096-2] [Medline: 28433615]

23. Bert F, Giacometti M, Gualano MR, Siliquini R. Smartphones and health promotion: a review of the evidence. J Med Syst 2014 Jan;38(1):9995. [doi: 10.1007/s10916-013-9995-7] [Medline: 24346929]

24. Fischer F. Digital interventions in prevention and health promotion: What kind of evidence do we have and what is needed? Bundesgesundheitsblatt Gesundheitsforschung Gesundheitsschutz 2020 Jun 30;63(6):674-680. [doi: 10.1007/s00103-020-03143-6] [Medline: 32355991]

25. Tricco AC, Lillie E, Zarin W, O'Brien KK, Colquhoun H, Levac D, et al. PRISMA Extension for Scoping Reviews (PRISMA-ScR): Checklist and Explanation. Ann Intern Med 2018 Sep 04;169(7):467. [doi: 10.7326/M18-0850]

26. Peters MDJ, Godfrey CM, Khalil H, McInerney P, Parker D, Soares CB. Guidance for conducting systematic scoping reviews. Int J Evid Based Healthc 2015 Sep;13(3):141-146. [doi: 10.1097/XEB.0000000000000050] [Medline: 26134548]

27. Arksey H, O'Malley L. Scoping studies: towards a methodological framework. International Journal of Social Research Methodology 2005 Feb;8(1):19-32. [doi: 10.1080/1364557032000119616]

28. Levac D, Colquhoun H, O'Brien KK. Scoping studies: advancing the methodology. Implement Sci 2010 Sep 20;5(1):69 [FREE Full text] [doi: 10.1186/1748-5908-5-69] [Medline: 20854677]

29. Peters M, Godfrey C, McInerney P, Munn Z, Tricco A, Khalil H. Chapter 11: Scoping Reviews. In: Aromataris E, Munn Z, editors. Joanna Briggs Institute Reviewer's Manual. Adelaide: Joanna Briggs Institute; 2020.

30. Leppin A. Konzepte der Prävention, Strategien. In: Hurrelmann K, Klotz T, Haisch J, editors. Lehrbuch Prävention und Gesundheitsförderung. Bern: Verlag Hans Huber; 2014:36-44.

31. Altgeld T, Kolip P. Konzepte Strategien der Gesundheitsförderung. In: Hurrelmann K, Klotz T, Haisch J, editors. Lehrbuch Prävention und Gesundheitsförderung. Bern: Verlag Hans Huber; 2014:45-56.

32. GKV-Spitzenverband. Leitfaden Prävention-Handlungsfelder und Kriterien nach §; 201820 Abs 2 SGB V. 2020. URL: https://www.gkv-spitzenverband.de/media/dokumente/krankenversicherung_1/praevention_selbsthilfe_beratung/ praevention/praevention leitfaden/Leitfaden Pravention 2020 barrierefrei.pdf [accessed 2022-01-04]

33. Evens A. Logic of the digital. London, UK: Bloomsbury; 2015. 
34. O'Neil A, Cocker F, Rarau P, Baptista S, Cassimatis M, Barr Taylor C, et al. Using digital interventions to improve the cardiometabolic health of populations: a meta-review of reporting quality. J Am Med Inform Assoc 2017 Jul 01;24(4):867-879 [FREE Full text] [doi: 10.1093/jamia/ocw166] [Medline: 28339628]

35. Moher D, Liberati A, Tetzlaff J, Altman DG, PRISMA Group. Preferred reporting items for systematic reviews and meta-analyses: the PRISMA statement. PLoS Med 2009 Jul 21;6(7):e1000097 [FREE Full text] [doi: 10.1371/journal.pmed.1000097] [Medline: 19621072]

36. Duncan DT, Aldstadt J, Whalen J, Melly SJ, Gortmaker SL. Validation of walk score for estimating neighborhood walkability: an analysis of four US metropolitan areas. Int J Environ Res Public Health 2011 Nov 04;8(11):4160-4179 [FREE Full text] [doi: 10.3390/ijerph8114160] [Medline: 22163200]

37. Anderson-Hanley C, Arciero PJ, Brickman AM, Nimon JP, Okuma N, Westen SC, et al. Exergaming and older adult cognition: a cluster randomized clinical trial. Am J Prev Med 2012 Feb;42(2):109-119. [doi: 10.1016/j.amepre.2011.10.016] [Medline: 22261206]

38. Dias JD, Mekaro MS, Cheng Lu JK, Otsuka JL, Fonseca LMM, Zem-Mascarenhas SH. Serious game development as a strategy for health promotion and tackling childhood obesity. Rev Lat Am Enfermagem 2016 Aug 15;24:e2759 [FREE Full text] [doi: 10.1590/1518-8345.1015.2759] [Medline: 27533268]

39. Luz S, Masoodian M, Cesario RR, Cesario M. Using a serious game to promote community-based awareness and prevention of neglected tropical diseases. Entertainment Computing 2016 Jun;15:43-55. [doi: 10.1016/j.entcom.2015.11.001]

40. Byun W, Lau E, Brusseau T. Feasibility and Effectiveness of a Wearable Technology-Based Physical Activity Intervention in Preschoolers: A Pilot Study. Int J Environ Res Public Health 2018 Aug 23;15(9):1821 [FREE Full text] [doi: 10.3390/ijerph15091821] [Medline: 30142911]

41. Duncan M, Staples V. The Impact of a School-Based Active Video Game Play Intervention on Children's Physical Activity During Recess. Human Movement 2010;11(1):95-99 [FREE Full text] [doi: 10.2478/v10038-009-0023-1]

42. Swindle TM, Ward WL, Whiteside-Mansell L. Facebook: The Use of Social Media to Engage Parents in a Preschool Obesity Prevention Curriculum. J Nutr Educ Behav 2018 Jan;50(1):4-10.e1 [FREE Full text] [doi: 10.1016/j.jneb.2017.05.344] [Medline: 29325661]

43. Sheats JL, Winter SJ, Romero PP, King AC. FEAST: Empowering Community Residents to Use Technology to Assess and Advocate for Healthy Food Environments. J Urban Health 2017 Apr 28;94(2):180-189 [FREE Full text] [doi: 10.1007/s11524-017-0141-6] [Medline: 28247054]

44. Yang Y, Kang B, Lee EY, Yang HK, Kim H, Lim S, et al. Effect of an obesity prevention program focused on motivating environments in childhood: a school-based prospective study. Int J Obes (Lond) 2017 Jul 20;41(7):1027-1034. [doi: 10.1038/ijo.2017.47] [Medline: 28216643]

45. King AC, Hekler EB, Grieco LA, Winter SJ, Sheats JL, Buman MP, et al. Effects of Three Motivationally Targeted Mobile Device Applications on Initial Physical Activity and Sedentary Behavior Change in Midlife and Older Adults: A Randomized Trial. PLoS One 2016;11(6):e0156370 [FREE Full text] [doi: 10.1371/journal.pone.0156370] [Medline: 27352250]

46. Bailey J, Tomlinson N, Hobbs L, Webster R. Challenges and opportunities in evaluating a digital sexual health intervention in a clinic setting: Staff and patient views. Digit Health 2017 Apr 11;3:2055207617704272 [FREE Full text] [doi: 10.1177/2055207617704272] [Medline: 29942593]

47. Loss J, Lindacher V, Curbach J. Online social networking sites-a novel setting for health promotion? Health Place 2014 Mar;26:161-170. [doi: 10.1016/j.healthplace.2013.12.012] [Medline: 24457613]

48. Kolt GS, Rosenkranz RR, Savage TN, Maeder AJ, Vandelanotte C, Duncan MJ, et al. WALK 2.0 - using Web 2.0 applications to promote health-related physical activity: a randomised controlled trial protocol. BMC Public Health 2013 May 03;13(1):436 [FREE Full text] [doi: 10.1186/1471-2458-13-436] [Medline: 23642010]

49. Bourdeaudhuij ID, Maes L, De Henauw S, De Vriendt T, Moreno LA, Kersting M, HELENA Study Group. Evaluation of a computer-tailored physical activity intervention in adolescents in six European countries: the Activ-O-Meter in the HELENA intervention study. J Adolesc Health 2010 May;46(5):458-466. [doi: 10.1016/j.jadohealth.2009.10.006] [Medline: 20413082]

50. Templeton M, Kelly C, Lohan M. Developing a Sexual Health Promotion Intervention With Young Men in Prisons: A Rights-Based Participatory Approach. JMIR Res Protoc 2019 Apr 29;8(4):e11829 [FREE Full text] [doi: 10.2196/11829] [Medline: 31033447]

51. Delaney T, Wyse R, Yoong SL, Sutherland R, Wiggers J, Ball K, et al. Cluster randomized controlled trial of a consumer behavior intervention to improve healthy food purchases from online canteens. Am J Clin Nutr 2017 Nov 27;106(5):1311-1320. [doi: 10.3945/ajcn.117.158329] [Medline: 28971849]

52. Allison S, Bauermeister JA, Bull S, Lightfoot M, Mustanski B, Shegog R, et al. The intersection of youth, technology, and new media with sexual health: moving the research agenda forward. J Adolesc Health 2012 Sep;51(3):207-212 [FREE Full text] [doi: 10.1016/j.jadohealth.2012.06.012] [Medline: 22921129]

53. Apolinário-Hagen J, Groenewold SD, Fritsche L, Kemper J, Krings L, Salewski C. Die Gesundheit Fernstudierender stärken. Präv Gesundheitsf 2017 Oct 17;13(2):151-158. [doi: 10.1007/s11553-017-0620-3]

54. Atkinson AM, Sumnall H, Measham F. Depictions of alcohol use in a UK Government partnered online social marketing campaign:. Drugs: Education, Prevention and Policy 2011 Jan 05;18(6):454-467. [doi: 10.3109/09687637.2010.534745] 
55. Azevedo J, Padrão P, Gregório MJ, Almeida C, Moutinho N, Lien N, et al. A Web-Based Gamification Program to Improve Nutrition Literacy in Families of 3- to 5-Year-Old Children: The Nutriscience Project. J Nutr Educ Behav 2019 Mar;51(3):326-334. [doi: 10.1016/j.jneb.2018.10.008] [Medline: 30579894]

56. Backonja U, Hall AK, Thielke S. Older Adults' Current and Potential Uses of Information Technologies in a Changing World: A Theoretical Perspective. Int J Aging Hum Dev 2014 Dec 01;80(1):41-63 [FREE Full text] [doi: 10.1177/0091415015591109] [Medline: 26215298]

57. Bailey JV, Webster R, Hunter R, Griffin M, Freemantle N, Rait G, et al. The Men's Safer Sex project: intervention development and feasibility randomised controlled trial of an interactive digital intervention to increase condom use in men. Health Technol Assess 2016 Dec;20(91):1-124 [FREE Full text] [doi: 10.3310/hta20910] [Medline: 27966409]

58. Bamidis P, Konstantinidis E, Billis A, Frantzidis C, Tsolaki M, Tsolaki W, et al. A Web services-based exergaming platform for senior citizens: The long lasting memories project approach to e-health care. In: Proceedings of the Annual International Conference of the IEEE Engineering in Medicine and Biology Society. 2011 Presented at: Annual International Conference of the IEEE Engineering in Medicine and Biology Society; 30 Aug.-3 Sept. 2011; Boston, MA, USA. [doi: 10.1109/iembs.2011.6090694]

59. Baranowski T, Blumberg F, Buday R, DeSmet A, Fiellin LE, Green CS, et al. Games for Health for Children-Current Status and Needed Research. Games Health J 2016 Feb;5(1):1-12 [FREE Full text] [doi: 10.1089/g4h.2015.0026] [Medline: 26262772]

60. Beck AM, Eyler AA, Aaron Hipp J, King AC, Tabak RG, Yan Y, et al. A multilevel approach for promoting physical activity in rural communities: a cluster randomized controlled trial. BMC Public Health 2019 Jan 30;19(1):126 [FREE Full text] [doi: 10.1186/s12889-019-6443-8] [Medline: 30700262]

61. Betsch C, Brewer NT, Brocard P, Davies P, Gaissmaier W, Haase N, et al. Opportunities and challenges of Web 2.0 for vaccination decisions. Vaccine 2012 May 28;30(25):3727-3733. [doi: 10.1016/j.vaccine.2012.02.025] [Medline: 22365840]

62. Bickmore TW, Silliman RA, Nelson K, Cheng DM, Winter M, Henault L, et al. A randomized controlled trial of an automated exercise coach for older adults. J Am Geriatr Soc 2013 Oct;61(10):1676-1683. [doi: 10.1111/jgs.12449] [Medline: 24001030]

63. Brüll P, Ruiter RAC, Wiers RW, Kok G. Gaming for Safer Sex: Young German and Turkish People Report No Specific Culture-Related Preferences Toward Educational Games Promoting Safer Sex. Games Health J 2016 Sep 28. [doi: 10.1089/g4h.2016.0016] [Medline: 27680494]

64. Buendía Eisman A, Arias Santiago S, Moreno-Gimenez J, Cabrera-León A, Prieto L, Castillejo I, et al. An Internet-based programme to promote adequate UV exposure behaviour in adolescents in Spain. J Eur Acad Dermatol Venereol 2013 Apr;27(4):442-453. [doi: 10.1111/j.1468-3083.2012.04455.x] [Medline: 22329864]

65. Bull SS, Levine DK, Black SR, Schmiege SJ, Santelli J. Social media-delivered sexual health intervention: a cluster randomized controlled trial. Am J Prev Med 2012 Nov;43(5):467-474 [FREE Full text] [doi: 10.1016/j.amepre.2012.07.022] [Medline: 23079168]

66. Buller DB, Andersen PA, Walkosz BJ, Scott MD, Beck L, Cutter GR. Effect of an intervention on observed sun protection by vacationers in a randomized controlled trial at North American resorts. Prev Med 2017 Jun;99:29-36 [FREE Full text] [doi: 10.1016/j.ypmed.2017.01.014] [Medline: 28189810]

67. Buman MP, Winter SJ, Sheats JL, Hekler EB, Otten JJ, Grieco LA, et al. The Stanford Healthy Neighborhood Discovery Tool: a computerized tool to assess active living environments. Am J Prev Med 2013 Apr;44(4):e41-e47 [FREE Full text] [doi: 10.1016/j.amepre.2012.11.028] [Medline: 23498112]

68. Byrd-Bredbenner C, Delaney C, Martin-Biggers J, Koenings M, Quick V. The marketing plan and outcome indicators for recruiting and retaining parents in the HomeStyles randomized controlled trial. Trials 2017 Nov 15;18(1):540 [FREE Full text] [doi: 10.1186/s13063-017-2262-3] [Medline: 29141692]

69. Byrd-Bredbenner C, Martin-Biggers J, Koenings M, Quick V, Hongu N, Worobey J. HomeStyles, A Web-Based Childhood Obesity Prevention Program for Families With Preschool Children: Protocol for a Randomized Controlled Trial. JMIR Res Protoc 2017 Apr 25;6(4):e73 [FREE Full text] [doi: 10.2196/resprot.7544] [Medline: 28442452]

70. Byrd-Bredbenner C, Martin-Biggers J, Povis GA, Worobey J, Hongu N, Quick V. Promoting healthy home environments and lifestyles in families with preschool children: HomeStyles, a randomized controlled trial. Contemp Clin Trials 2018 Jan;64:139-151. [doi: 10.1016/j.cct.2017.10.012] [Medline: 29079392]

71. Calear AL, Batterham PJ, Poyser CT, Mackinnon AJ, Griffiths KM, Christensen H. Cluster randomised controlled trial of the e-couch Anxiety and Worry program in schools. J Affect Disord 2016 May 15;196:210-217. [doi: 10.1016/j.jad.2016.02.049] [Medline: 26926660]

72. Calear AL, Christensen H, Griffiths KM, Mackinnon A. The Y-Worri Project: study protocol for a randomised controlled trial. Trials 2013 Mar 19;14:76 [FREE Full text] [doi: 10.1186/1745-6215-14-76] [Medline: 23506049]

73. Caperchione CM, Kolt GS, Savage TN, Rosenkranz RR, Maeder AJ, Vandelanotte C, et al. WALK 2.0: examining the effectiveness of Web 2.0 features to increase physical activity in a 'real world' setting: an ecological trial. BMJ Open 2014 Oct 10;4(10):e006374 [FREE Full text] [doi: 10.1136/bmjopen-2014-006374] [Medline: 25304191] 
74. Carah N, Meurk C, Angus D. Online self-expression and experimentation as 'reflectivism': Using text analytics to examine the participatory forum Hello Sunday Morning. Health (London) 2017 Mar 26;21(2):119-135. [doi: 10.1177/1363459315596799] [Medline: 26216897]

75. Carlfjord S, Lindberg M, Andersson A. Staff perceptions of addressing lifestyle in primary health care: a qualitative evaluation 2 years after the introduction of a lifestyle intervention tool. BMC Fam Pract 2012 Oct 10;13(1):99 [FREE Full text] [doi: 10.1186/1471-2296-13-99] [Medline: 23052150]

76. Carr LJ, Dunsiger SI, Marcus BH. Walk score ${ }^{\mathrm{TM}}$ as a global estimate of neighborhood walkability. Am J Prev Med 2010 Nov;39(5):460-463 [FREE Full text] [doi: 10.1016/j.amepre.2010.07.007] [Medline: 20965384]

77. Carr LJ, Dunsiger SI, Lewis B, Ciccolo JT, Hartman S, Bock B, et al. Randomized controlled trial testing an internet physical activity intervention for sedentary adults. Health Psychol 2013 Mar;32(3):328-336 [FREE Full text] [doi: 10.1037/a0028962] [Medline: 22823069]

78. Cavallo DN, Brown JD, Tate DF, DeVellis RF, Zimmer C, Ammerman AS. The role of companionship, esteem, and informational support in explaining physical activity among young women in an online social network intervention. J Behav Med 2014 Oct 1;37(5):955-966 [FREE Full text] [doi: 10.1007/s10865-013-9534-5] [Medline: 24081454]

79. Cavallo DN, Tate DF, Ries AV, Brown JD, DeVellis RF, Ammerman AS. A social media-based physical activity intervention: a randomized controlled trial. Am J Prev Med 2012 Nov;43(5):527-532 [FREE Full text] [doi: 10.1016/j.amepre.2012.07.019] [Medline: 23079176]

80. Champion KE, Newton NC, Stapinski L, Slade T, Barrett EL, Teesson M. A cross-validation trial of an Internet-based prevention program for alcohol and cannabis: Preliminary results from a cluster randomised controlled trial. Aust N Z J Psychiatry 2016 Jan;50(1):64-73. [doi: 10.1177/0004867415577435] [Medline: 25801662]

81. Champion KE, Newton NC, Stapinski LA, Teesson M. Effectiveness of a universal internet-based prevention program for ecstasy and new psychoactive substances: a cluster randomized controlled trial. Addiction 2016 Aug 13;111(8):1396-1405. [doi: 10.1111/add.13345] [Medline: 26880476]

82. Champion KE, Newton NC, Stapinski L, Teesson M. Cluster randomised controlled trial of an online intervention to prevent ecstasy and new psychoactive substance use among adolescents: final results and implications for implementation. BMJ Open 2018 Nov 25;8(11):e020433 [FREE Full text] [doi: 10.1136/bmjopen-2017-020433] [Medline: $\underline{\text { 30478103] }}$

83. Chandra PS, Sowmya H, Mehrotra S, Duggal M. 'SMS' for mental health—feasibility and acceptability of using text messages for mental health promotion among young women from urban low income settings in India. Asian J Psychiatr 2014 Oct;11:59-64. [doi: 10.1016/j.ajp.2014.06.008] [Medline: 25453699]

84. Chen ACC, Amresh A. Developing a Bilingual, Computer-Tailored, HPV Vaccination Promotion Intervention Targeting Latino Parents. In: Proceedings of the 5th International Conference on Digital Health 2015. 2015 Presented at: DH '15: Digital Health 2015 Conference; May 18 - 20, 201; Florence Italy p. 59-64. [doi: 10.1145/2750511.2750522]

85. Chen L, Wang W, Du X, Rao X, van Velthoven MH, Yang R, et al. Effectiveness of a smart phone app on improving immunization of children in rural Sichuan Province, China: study protocol for a paired cluster randomized controlled trial. BMC Public Health 2014 Mar 20;14(1):262 [FREE Full text] [doi: 10.1186/1471-2458-14-262] [Medline: 24645829]

86. Cook TL, De Bourdeaudhuij I, Maes L, Haerens L, Grammatikaki E, Widhalm K, et al. Moderators of the effectiveness of a web-based tailored intervention promoting physical activity in adolescents: the HELENA Activ-O-Meter. J Sch Health 2014 Apr 11;84(4):256-266. [doi: 10.1111/josh.12140] [Medline: 24617909]

87. Cook T, De Bourdeaudhuij I, Maes L, Haerens L, Grammatikaki E, Widhalm K, et al. Psychosocial determinants and perceived environmental barriers as mediators of the effectiveness of a web-based tailored intervention promoting physical activity in adolescents: the HELENA Activ-O-Meter. J Phys Act Health 2014 May;11(4):741-751. [doi: 10.1123/jpah.2012-0120] [Medline: 23676337]

88. Crawford G, Maycock B, Tobin R, Brown G, Lobo R. Prevention of HIV and Other Sexually Transmissible Infections in Expatriates and Traveler Networks: Qualitative Study of Peer Interaction in an Online Forum. J Med Internet Res 2018 Sep 05;20(9):e10787 [FREE Full text] [doi: 10.2196/10787] [Medline: 30185404]

89. Cullen KW, Thompson D, Chen T. Outcome Evaluation of Family Eats. Health Educ Behav 2017 Feb 09;44(1):32-40. [doi: 10.1177/1090198116643917] [Medline: 27198535]

90. „fit4future“: 1.200 neue Schulen und Kitas. DAK Gesundheit. 2020. URL: https://www.dak.de/dak/bundesthemen/ fit4future-1-200-neue-schulen-und-kitas-2103614.html [accessed 2020-05-15]

91. Daley MF, Narwaney KJ, Shoup JA, Wagner NM, Glanz JM. Addressing Parents' Vaccine Concerns: A Randomized Trial of a Social Media Intervention. Am J Prev Med 2018 Jul;55(1):44-54. [doi: 10.1016/j.amepre.2018.04.010] [Medline: 29773490]

92. Davies C, Corry K, Van IA, Vandelanotte C, Caperchione C, Mummery WK. Prospective associations between intervention components and website engagement in a publicly available physical activity website: the case of 10,000 Steps Australia. J Med Internet Res 2012 Jan 11;14(1):e4 [FREE Full text] [doi: 10.2196/jmir.1792] [Medline: 22260810]

93. Degroote L, Plaete J, De Bourdeaudhuij I, Verloigne M, Van Stappen V, De Meester A, et al. The Effect of the eHealth Intervention 'MyPlan 1.0' on Physical Activity in Adults Who Visit General Practice: A Quasi-Experimental Trial. Int J Environ Res Public Health 2018 Jan 30;15(2):228 [FREE Full text] [doi: 10.3390/ijerph15020228] [Medline: 29385770] 
94. Dixon BE, Zimet GD, Xiao S, Tu W, Lindsay B, Church A, et al. An Educational Intervention to Improve HPV Vaccination: A Cluster Randomized Trial. Pediatrics 2019 Jan 10;143(1):e20181457. [doi: 10.1542/peds.2018-1457] [Medline: 30530637]

95. Dour CA, Horacek TM, Schembre SM, Lohse B, Hoerr S, Kattelmann K, et al. Process evaluation of Project WebHealth: a nondieting Web-based intervention for obesity prevention in college students. J Nutr Educ Behav 2013 Jul;45(4):288-295. [doi: 10.1016/j.jneb.2012.10.001] [Medline: 23410994]

96. Duncan DT. What's your Walk Score ${ }^{\circ}$ ?: Web-based neighborhood walkability assessment for health promotion and disease prevention. Am J Prev Med 2013 Aug;45(2):244-245. [doi: 10.1016/j.amepre.2013.04.008] [Medline: 23867033]

97. Dway NS, Soonthornworasiri N, Jandee K, Lawpoolsri S, Pan-Ngum W, Sinthuvanich D, et al. Effects of edutainment on knowledge and perceptions of Lisu mothers about the immunisation of their children. Health Education Journal 2015 Jan 23;75(2):131-143. [doi: 10.1177/0017896915569086]

98. Ehlers DK, Huberty JL, de Vreede GJ. Can an evidence-based book club intervention delivered via a tablet computer improve physical activity in middle-aged women? Telemed J E Health 2015 Feb;21(2):125-131. [doi: 10.1089/tmj.2013.0360] [Medline: 25526014]

99. Ekberg J, Timpka T, Angbratt M, Frank L, Norén AM, Hedin L, et al. Design of an online health-promoting community: negotiating user community needs with public health goals and service capabilities. BMC Health Serv Res 2013 Jul 04;13(1):258 [FREE Full text] [doi: 10.1186/1472-6963-13-258] [Medline: 23826944]

100. Ekram S, Debiec KE, Pumper MA, Moreno MA. Content and Commentary: HPV Vaccine and YouTube. J Pediatr Adolesc Gynecol 2019 Apr;32(2):153-157. [doi: 10.1016/j.jpag.2018.11.001] [Medline: 30445163]

101. Eschenbeck H, Lehner L, Hofmann H, Bauer S, Becker K, Diestelkamp S, ProHEAD Consortium. School-based mental health promotion in children and adolescents with StresSOS using online or face-to-face interventions: study protocol for a randomized controlled trial within the ProHEAD Consortium. Trials 2019 Jan 18;20(1):64 [FREE Full text] [doi: 10.1186/s13063-018-3159-5] [Medline: 30658675]

102. Ezendam NP, Burg J, Borsboom G, van Empelen P, Oenema A. Differential effects of the computer-tailored FATaintPHAT programme on dietary behaviours according to sociodemographic, cognitive and home environmental factors. Public Health Nutr 2012 Dec 21;17(02):431-439. [doi: 10.1017/s1368980012005344]

103. Ezendam NPM, Brug J, Oenema A. Evaluation of the Web-based computer-tailored FATaintPHAT intervention to promote energy balance among adolescents: results from a school cluster randomized trial. Arch Pediatr Adolesc Med 2012 Mar 05;166(3):248-255. [doi: 10.1001/archpediatrics.2011.204] [Medline: 22064878]

104. Fiellin LE, Kyriakides TC, Hieftje KD, Pendergrass TM, Duncan LR, Dziura JD, et al. The design and implementation of a randomized controlled trial of a risk reduction and human immunodeficiency virus prevention videogame intervention in minority adolescents: PlayForward: Elm City Stories. Clin Trials 2016 Aug;13(4):400-408. [doi: 10.1177/1740774516637871] [Medline: 27013483]

105. Gabarron E, Serrano JA, Wynn R, Armayones M. Avatars using computer/smartphone mediated communication and social networking in prevention of sexually transmitted diseases among North-Norwegian youngsters. BMC Med Inform Decis Mak 2012 Oct 30;12(1):120 [FREE Full text] [doi: 10.1186/1472-6947-12-120] [Medline: 23110684]

106. Ganz T, Braun M, Laging M, Schermelleh-Engel K, Michalak J, Heidenreich T. Effects of a stand-alone web-based electronic screening and brief intervention targeting alcohol use in university students of legal drinking age: A randomized controlled trial. Addict Behav 2018 Feb;77:81-88. [doi: 10.1016/j.addbeh.2017.09.017] [Medline: 28985586]

107. García-Camacha A, García-Camacha I, Martínez-Andrés M, Notario-Pacheco B, Rodríguez-Martín B. Pilot testing the effectiveness of the Healthy Ageing Supported by Internet and Community programme for promoting healthy lifestyles for people over 65 years of age. Scand J Caring Sci 2020 Sep 15;34(3):636-647. [doi: 10.1111/scs.12765] [Medline: $\underline{31614020]}$

108. Gilliland J, Sadler R, Clark A, O'Connor C, Milczarek M, Doherty S. Using a Smartphone Application to Promote Healthy Dietary Behaviours and Local Food Consumption. Biomed Res Int 2015;2015:841368 [FREE Full text] [doi: 10.1155/2015/841368] [Medline: 26380298]

109. Gold J, Pedrana AE, Stoove MA, Chang S, Howard S, Asselin J, et al. Developing health promotion interventions on social networking sites: recommendations from The FaceSpace Project. J Med Internet Res 2012 Feb 28;14(1):e30 [FREE Full text] [doi: 10.2196/jmir.1875] [Medline: 22374589]

110. González C, Herrero P, Cubero JM, Iniesta JM, Hernando ME, García-Sáez G, et al. PREDIRCAM eHealth platform for individualized telemedical assistance for lifestyle modification in the treatment of obesity, diabetes, and cardiometabolic risk prevention: a pilot study (PREDIRCAM 1). J Diabetes Sci Technol 2013 Jul 01;7(4):888-897 [FREE Full text] [doi: 10.1177/193229681300700411] [Medline: 23911170]

111. Grabowski D. Health identity, participation and knowledge: A qualitative study of a computer game for health education among adolescents in Denmark. Health Education Journal 2013 Jan 14;72(6):761-768. [doi: 10.1177/0017896912469559]

112. Graham ML, Uesugi KH, Niederdeppe J, Gay GK, Olson CM. The theory, development, and implementation of an e-intervention to prevent excessive gestational weight gain: e-Moms Roc. Telemed J E Health 2014 Dec;20(12):1135-1142 [FREE Full text] [doi: 10.1089/tmj.2013.0354] [Medline: 25354350] 
113. Graham ML, Strawderman MS, Demment M, Olson CM. Does Usage of an eHealth Intervention Reduce the Risk of Excessive Gestational Weight Gain? Secondary Analysis From a Randomized Controlled Trial. J Med Internet Res 2017 Jan 09;19(1):e6 [FREE Full text] [doi: 10.2196/jmir.6644] [Medline: 28069560]

114. Greaney ML, Puleo E, Bennett GG, Haines J, Viswanath K, Gillman MW, et al. Factors associated with choice of web or print intervention materials in the healthy directions 2 study. Health Educ Behav 2014 Feb;41(1):52-62 [FREE Full text] [doi: 10.1177/1090198113486803] [Medline: 23720532]

115. Grim M, Hortz B, Petosa R. Impact Evaluation of a Pilot Web-Based Intervention to Increase Physical Activity. Am J Health Promot 2011 Mar 01;25(4):227-230. [doi: 10.4278/ajhp.081216-arb-307]

116. Grindell C, Mawson S, Gerrish K, Parker S, Bissell P. Exploring the acceptability and usability of a novel social innovation to encourage physical activity: The iStep prototype. Health Soc Care Community 2019 Mar 26;27(2):383-391. [doi: 10.1111/hsc.12656] [Medline: $\underline{30255638]}$

117. Gubrium AC, Fiddian-Green A, Lowe S, DiFulvio G, Del Toro-Mejías L. Measuring Down: Evaluating Digital Storytelling as a Process for Narrative Health Promotion. Qual Health Res 2016 Nov 09;26(13):1787-1801. [doi: 10.1177/1049732316649353] [Medline: 27184518]

118. Gustafson A, Jilcott Pitts S, McQuerry K, Babtunde O, Mullins J. A Mentor-Led Text-Messaging Intervention Increases Intake of Fruits and Vegetables and Goal Setting for Healthier Dietary Consumption among Rural Adolescents in Kentucky and North Carolina, 2017. Nutrients 2019 Mar 11;11(3):593 [FREE Full text] [doi: 10.3390/nu11030593] [Medline: $\underline{30862118}$

119. Haruna H, Hu X, Chu S, Mellecker R. Initial Validation of the MAKE Framework: A Comprehensive Instrument for Evaluating the Efficacy of Game-Based Learning and Gamification in Adolescent Sexual Health Literacy. Ann Glob Health 2019 Feb 28;85(1):A [FREE Full text] [doi: 10.5334/aogh.1110] [Medline: 30873788]

120. Haruna H, Zainuddin Z, Mellecker RR, Chu SK, Hu X. An iterative process for developing digital gamified sexual health education for adolescent students in low-tech settings. ILS 2019 Nov 11;120(11/12):723-742. [doi: 10.1108/ils-07-2019-0066]

121. Haug S, Paz Castro R, Meyer C, Filler A, Kowatsch T, Schaub MP. A Mobile Phone-Based Life Skills Training Program for Substance Use Prevention Among Adolescents: Pre-Post Study on the Acceptance and Potential Effectiveness of the Program, Ready4life. JMIR Mhealth Uhealth 2017;5(10):e143 [FREE Full text] [doi: 10.2196/mhealth.8474] [Medline: 28978498]

122. Haug S, Paz Castro R, Wenger A, Schaub MP. Efficacy of a mobile phone-based life-skills training program for substance use prevention among adolescents: study protocol of a cluster-randomised controlled trial. BMC Public Health 2018 Sep 10;18(1):1102 [FREE Full text] [doi: 10.1186/s12889-018-5969-5] [Medline: $\underline{\text { 30200928] }}$

123. Helander E, Kaipainen K, Korhonen I, Wansink B. Factors related to sustained use of a free mobile app for dietary self-monitoring with photography and peer feedback: retrospective cohort study. J Med Internet Res 2014;16(4):e109 [FREE Full text] [doi: 10.2196/jmir.3084] [Medline: 24735567]

124. Horstmann D, Tolks D, Dadaczynski K, Paulus P. Förderung des Wohlbefindens durch „Gamification“. Präv Gesundheitsf 2018 Jul 20;13(4):305-311. [doi: 10.1007/s11553-018-0659-9]

125. Huang S, Hung W, Shyu M, Chang K, Chen C. Web-based intervention to promote physical activity in Taiwanese children. J Pediatr Nurs 2019 Mar;45:e35-e43. [doi: 10.1016/j.pedn.2018.12.016] [Medline: 30700375]

126. Hyden C, Cohall A. Innovative approaches to using new media and technology in health promotion for adolescents and young adults. In: AM:STARs: Advances In Health Promotion for Adolescents and Young Adults. Itasca, Illinois, United States: American Academy of Pediatrics; 2005:498-520.

127. Irwin B, Kurz D, Chalin P, Thompson N. Testing the Efficacy of OurSpace, a Brief, Group Dynamics-Based Physical Activity Intervention: A Randomized Controlled Trial. J Med Internet Res 2016 May 06;18(4):e87 [FREE Full text] [doi: 10.2196/jmir.5342] [Medline: 27154301]

128. Jaganath D, Gill HK, Cohen AC, Young SD. Harnessing Online Peer Education (HOPE): integrating C-POL and social media to train peer leaders in HIV prevention. AIDS Care 2012 May;24(5):593-600 [FREE Full text] [doi: 10.1080/09540121.2011.630355] [Medline: 22149081]

129. Kattelmann KK, Bredbenner CB, White AA, Greene GW, Hoerr SL, Kidd T, et al. The effects of Young Adults Eating and Active for Health (YEAH): a theory-based Web-delivered intervention. J Nutr Educ Behav 2014 Nov;46(6):S27-S41. [doi: 10.1016/j.jneb.2014.08.007] [Medline: 25457733]

130. Kattelmann KK, White AA, Greene GW, Byrd-Bredbenner C, Hoerr SL, Horacek TM, et al. Development of Young Adults Eating and Active for Health (YEAH) internet-based intervention via a community-based participatory research model. J Nutr Educ Behav 2014 Mar;46(2):S10-S25. [doi: 10.1016/j.jneb.2013.11.006] [Medline: 24456834]

131. InCogito. Kaufmännische Krankenkasse. 2020. URL: https://www.kkh.de/leistungen/praevention-vorsorge/ gesundheitsfoerderung-setting/incogito [accessed 2020-05-15]

132. Kim HK, Niederdeppe J, Guillory J, Graham M, Olson C, Gay G. Determinants of Pregnant Women's Online Self-Regulatory Activities for Appropriate Gestational Weight Gain. Health Commun 2015 Sep 10;30(9):922-932 [FREE Full text] [doi: 10.1080/10410236.2014.905900] [Medline: 25205417] 
133. King A, Winter S, Sheats J, Rosas LG, Buman MP, Salvo D, et al. Leveraging Citizen Science and Information Technology for Population Physical Activity Promotion. Transl J Am Coll Sports Med 2016 May 15;1(4):30-44 [FREE Full text] [Medline: 27525309]

134. Knöll M, Moar M. The Space of Digital Health Games. International Journal of Computer Science in Sport 2012;11(1):61-72 [FREE Full text]

135. Knöll M. Mobile Partizipation in der gesundheitsfördernden Stadtgestaltung_zwei Fallbeispiele zu Datenerfassung und Interaktion im Stadtraum. In: Baumgart S, Köckler H, Ritzinger A, Rüdiger A, editors. Planung für gesundheitsfördernde Städte. Hannover: ARL - Akademie für Raumentwicklung in der Leibniz-Gemeinschaft; 2018:387-401.

136. Knöll M. Urban health games. Collaborative, expressive and reflective. Dissertation, University of Stuttgart. 2012. URL: https://elib.uni-stuttgart.de/handle/11682/109 [accessed 2021-12-23]

137. Knowlden AP, Conrad E. Two-Year Outcomes of the Enabling Mothers to Prevent Pediatric Obesity Through Web-Based Education and Reciprocal Determinism (EMPOWER) Randomized Control Trial. Health Educ Behav 2018 Apr 27;45(2):262-276. [doi: 10.1177/1090198117732604] [Medline: 28954544]

138. Knowlden AP, Sharma M, Cottrell RR, Wilson BRA, Johnson ML. Impact evaluation of Enabling Mothers to Prevent Pediatric Obesity through Web-Based Education and Reciprocal Determinism (EMPOWER) Randomized Control Trial. Health Educ Behav 2015 Apr;42(2):171-184. [doi: 10.1177/1090198114547816] [Medline: 25161168]

139. Konstantinidis E, Billis A, Hlauschek W, Panek P, Bamidis P. Integration of cognitive and physical training in a smart home environment for the elderly people. Studies in health technology and informatics 2010;160(1):58-62. [doi: 10.3233/978-1-60750-588-4-58]

140. Kousoulis AA, Kympouropoulos SP, Pouli DK, Economopoulos KP, Vardavas CI. From the Classroom to Facebook: A Fresh Approach for Youth Tobacco Prevention. Am J Health Promot 2016 May;30(5):390-393. [doi: 10.1177/0890117116646345] [Medline: 27404648]

141. Kröninger-Jungaberle H, Nagy E, von Heyden M, DuBois F, Ullrich J, Wippermann C, et al. REBOUND: A media-based life skills and risk education programme. Health Education Journal 2014 Nov 16;74(6):705-719. [doi: $10.1177 / 0017896914557097]$

142. Kuosmanen T, Fleming T, Barry M. The implementation of SPARX-R computerized mental health program in alternative education: Exploring the factors contributing to engagement and dropout. Children and Youth Services Review 2018 Jan;84:176-184. [doi: 10.1016/j.childyouth.2017.11.032]

143. Kuosmanen T, Fleming TM, Barry MM. Using Computerized Mental Health Programs in Alternative Education: Understanding the Requirements of Students and Staff. Health Commun 2018 Jun 20;33(6):753-761. [doi: 10.1080/10410236.2017.1309620] [Medline: 28426253]

144. Lakerveld J, Mackenbach JD, de Boer F, Brandhorst B, Broerse JEW, de Bruijn G, et al. Improving cardiometabolic health through nudging dietary behaviours and physical activity in low SES adults: design of the Supreme Nudge project. BMC Public Health 2018 Jul 20;18(1):899 [FREE Full text] [doi: 10.1186/s12889-018-5839-1] [Medline: 30029600]

145. Lana A, del Valle MO, López S, Faya-Ornia G, López ML. Study protocol of a randomized controlled trial to improve cancer prevention behaviors in adolescents and adults using a web-based intervention supplemented with SMS. BMC Public Health 2013 Apr 17;13(1):357 [FREE Full text] [doi: 10.1186/1471-2458-13-357] [Medline: 23594381]

146. Larsen B, Marcus B, Pekmezi D, Hartman S, Gilmer T. A Web-Based Physical Activity Intervention for Spanish-Speaking Latinas: A Costs and Cost-Effectiveness Analysis. J Med Internet Res 2017 Feb 22;19(2):e43 [FREE Full text] [doi: 10.2196/jmir.6257] [Medline: 28228368]

147. Laska MN, Sevcik SM, Moe SG, Petrich CA, Nanney MS, Linde JA, et al. A 2-year young adult obesity prevention trial in the US: Process evaluation results. Health Promot Int 2016 Dec 30;31(4):793-800 [FREE Full text] [doi: 10.1093/heapro/dav066] [Medline: 26135586]

148. Lima T, Beltrame J, Niquini C, Barbosa B, Davis C. Design of a Mixed-Reality Serious Game to Tackle a Public Health Problem. In: Proceedings of the 17th International Conference on Entertainment Computing (ICEC). 2018 Presented at: 17th International Conference on Entertainment Computing (ICEC); Sep 2018; Poznan, Poland p. 305-309 URL: https:/ /hal.inria.fr/hal-02128602/document

149. Little P, Stuart B, Hobbs FDR, Moore M, Barnett J, Popoola D, et al. An internet-delivered handwashing intervention to modify influenza-like illness and respiratory infection transmission (PRIMIT): a primary care randomised trial. The Lancet 2015 Oct;386(10004):1631-1639. [doi: 10.1016/s0140-6736(15)60127-1]

150. Loh IH, Schwendler T, Trude AC, Anderson Steeves ET, Cheskin LJ, Lange S, et al. Implementation of Text-Messaging and Social Media Strategies in a Multilevel Childhood Obesity Prevention Intervention: Process Evaluation Results. Inquiry 2018 Jun 04;55:46958018779189 [FREE Full text] [doi: 10.1177/0046958018779189] [Medline: 29865969]

151. Lombard C, Brennan L, Reid M, Klassen KM, Palermo C, Walker T, et al. Communicating health-Optimising young adults' engagement with health messages using social media: Study protocol. Nutr Diet 2018 Nov 15;75(5):509-519. [doi: 10.1111/1747-0080.12448] [Medline: 30009396]

152. Lumsden C, Wolf R, Contento I, Basch C, Zybert P, Koch P, et al. Feasibility, Acceptability, and Short-term Behavioral Impact of the MySmileBuddy Intervention for Early Childhood Caries. J Health Care Poor Underserved 2019;30(1):59-69. [doi: 10.1353/hpu.2019.0007] [Medline: 30827969] 
153. Lyson HC, Le GM, Zhang J, Rivadeneira N, Lyles C, Radcliffe K, et al. Social Media as a Tool to Promote Health Awareness: Results from an Online Cervical Cancer Prevention Study. J Cancer Educ 2019 Aug 11;34(4):819-822 [FREE Full text] [doi: 10.1007/s13187-018-1379-8] [Medline: 29948924]

154. Maes L, Cook TL, Ottovaere C, Matthijs C, Moreno LA, Kersting M, et al. Pilot evaluation of the HELENA (Healthy Lifestyle in Europe by Nutrition in Adolescence) Food-O-Meter, a computer-tailored nutrition advice for adolescents: a study in six European cities. Public Health Nutr 2011 Jul;14(7):1292-1302. [doi: 10.1017/S1368980010003563] [Medline: 21281542]

155. Magoc D, Tomaka J, Bridges-Arzaga A. Using the web to increase physical activity in college students. Am J Health Behav 2011;35(2):142-154. [doi: 10.5993/ajhb.35.2.2] [Medline: 21204677]

156. Maher C, Ferguson M, Vandelanotte C, Plotnikoff R, De Bourdeaudhuij I, Thomas S, et al. A Web-Based, Social Networking Physical Activity Intervention for Insufficiently Active Adults Delivered via Facebook App: Randomized Controlled Trial. J Med Internet Res 2015 Jul;17(7):e174 [FREE Full text] [doi: 10.2196/jmir.4086] [Medline: 26169067]

157. Mahmud AJ, Olander E, Eriksén S, Haglund BJ. Health communication in primary health care -a case study of ICT development for health promotion. BMC Med Inform Decis Mak 2013 Jan 30;13:17 [FREE Full text] [doi: 10.1186/1472-6947-13-17] [Medline: 23363566]

158. Malmberg M, Kleinjan M, Overbeek G, Vermulst A, Monshouwer K, Lammers J, et al. Effectiveness of the 'Healthy School and Drugs' prevention programme on adolescents' substance use: a randomized clustered trial. Addiction 2014 Jun;109(6):1031-1040. [doi: 10.1111/add.12526] [Medline: 24612164]

159. Manning J, Vandeusen K. Suicide prevention in the dot com era: technological aspects of a university suicide prevention program. J Am Coll Health 2011 Apr 13;59(5):431-433. [doi: 10.1080/07448480903540507] [Medline: 21500064]

160. Manzoor A, Mollee J, Araujo E, van Halteren A, Klein M. Online Sharing of Physical Activity: Does It Accelerate the Impact of a Health Promotion Program? In: Proceedings of the IEEE International Conferences on Big Data and Cloud Computing (BDCloud), Social Computing and Networking (SocialCom), Sustainable Computing and Communications (SustainCom) (BDCloud-SocialCom-SustainCom). 2016 Presented at: IEEE International Conferences on Big Data and Cloud Computing (BDCloud), Social Computing and Networking (SocialCom), Sustainable Computing and Communications (SustainCom) (BDCloud-SocialCom-SustainCom); 8-10 Oct. 2016; Atlanta, GA, USA p. 201-208. [doi: $\underline{10.1109 / \text { bdcloud-socialcom-sustaincom.2016.40] }}$

161. Martin CK, Nicklas T, Gunturk B, Correa JB, Allen HR, Champagne C. Measuring food intake with digital photography. J Hum Nutr Diet 2014 Jan;27 Suppl 1:72-81 [FREE Full text] [doi: 10.1111/jhn.12014] [Medline: 23848588]

162. Martin WH, Griest SE, Sobel JL, Howarth LC. Randomized trial of four noise-induced hearing loss and tinnitus prevention interventions for children. Int J Audiol 2013 Feb 04;52 Suppl 1(sup1):S41-S49. [doi: 10.3109/14992027.2012.743048] [Medline: 23373742]

163. McCormack GR, McFadden K, McHugh TF, Spence JC, Mummery K. Barriers and facilitators impacting the experiences of adults participating in an internet-facilitated pedometer intervention. Psychology of Sport and Exercise 2019

Nov;45:101549. [doi: 10.1016/j.psychsport.2019.101549]

164. McGloin AF, Eslami S. Digital and social media opportunities for dietary behaviour change. Proc Nutr Soc 2015 May;74(2):139-148. [doi: 10.1017/S0029665114001505] [Medline: 25319345]

165. Meng Y, Kim HC. Towards design of technologies persuading more physical activity. In: Proceedings of the IEEE 15 th International Conference on e-Health Networking, Applications and Services (Healthcom 2013). 2013 Presented at: IEEE 15th International Conference on e-Health Networking, Applications and Services (Healthcom 2013); 9-12 Oct. 2013; Lisbon. [doi: 10.1109/healthcom.2013.6720768]

166. Mitchell BL, Lewis NR, Smith AE, Rowlands AV, Parfitt G, Dollman J. Rural Environments and Community Health $(\mathrm{REACH})$ : a randomised controlled trial protocol for an online walking intervention in rural adults. BMC Public Health 2014 Sep 18;14(1):969 [FREE Full text] [doi: 10.1186/1471-2458-14-969] [Medline: 25236776]

167. Mitchell BL, Smith AE, Rowlands AV, Fraysse F, Parfitt G, Lewis NR, et al. Promoting physical activity in rural Australian adults using an online intervention. J Sci Med Sport 2019 Jan;22(1):70-75. [doi: 10.1016/j.jsams.2018.07.002] [Medline: $\underline{30031747]}$

168. Money AG, Atwal A, Boyce E, Gaber S, Windeatt S, Alexandrou K. Falls Sensei: a serious 3D exploration game to enable the detection of extrinsic home fall hazards for older adults. BMC Med Inform Decis Mak 2019 Apr 16;19(1):85 [FREE Full text] [doi: 10.1186/s12911-019-0808-x] [Medline: $\underline{\text { 30992072] }}$

169. Nahm E, Resnick B, Bellantoni M, Zhu S, Brown C, Brennan PF, et al. Dissemination of a theory-based online bone health program: Two intervention approaches. Health Informatics J 2015 Jun 28;21(2):120-136 [FREE Full text] [doi: 10.1177/1460458213505573] [Medline: 26021668]

170. Neiger BL, Thackeray R, Burton SH, Giraud-Carrier CG, Fagen MC. Evaluating social media's capacity to develop engaged audiences in health promotion settings: use of Twitter metrics as a case study. Health Promot Pract 2013 Mar;14(2):157-162. [doi: 10.1177/1524839912469378] [Medline: 23271716]

171. Newton NC, Teesson M, Vogl LE, Andrews G. Internet-based prevention for alcohol and cannabis use: final results of the Climate Schools course. Addiction 2010 Apr;105(4):749-759. [doi: 10.1111/j.1360-0443.2009.02853.x] [Medline: 20148791] 
172. Nitsch M, Adamcik T, Kuso S, Zeiler M, Waldherr K. Usability and Engagement Evaluation of an Unguided Online Program for Promoting a Healthy Lifestyle and Reducing the Risk for Eating Disorders and Obesity in the School Setting. Nutrients 2019 Mar 27;11(4):713 [FREE Full text] [doi: 10.3390/nu11040713] [Medline: 30934754]

173. O'Mara B. Social media, digital video and health promotion in a culturally and linguistically diverse Australia. Health Promot Int 2013 Sep 30;28(3):466-476. [doi: 10.1093/heapro/das014] [Medline: 22466682]

174. Paschall MJ, Antin T, Ringwalt CL, Saltz RF. Evaluation of an Internet-based alcohol misuse prevention course for college freshmen: findings of a randomized multi-campus trial. Am J Prev Med 2011 Sep;41(3):300-308 [FREE Full text] [doi: 10.1016/j.amepre.2011.03.021] [Medline: 21855745]

175. Payton F, Kvasny L. Online HIV awareness and technology affordance benefits for black female collegians - maybe not: the case of stigma. J Am Med Inform Assoc 2016 Nov;23(6):1121-1126. [doi: 10.1093/jamia/ocw017] [Medline: 27094988]

176. Peels DA, de Vries H, Bolman C, Golsteijn RHJ, van Stralen MM, Mudde AN, et al. Differences in the use and appreciation of a web-based or printed computer-tailored physical activity intervention for people aged over 50 years. Health Educ Res 2013 Aug 18;28(4):715-731. [doi: 10.1093/her/cyt065] [Medline: 23784076]

177. Peels DA, van Stralen MM, Bolman C, Golsteijn RH, de Vries H, Mudde AN, et al. Development of web-based computer-tailored advice to promote physical activity among people older than 50 years. J Med Internet Res 2012 Mar 02;14(2):e39 [FREE Full text] [doi: 10.2196/jmir.1742] [Medline: 22390878]

178. Peskin MF, Shegog R, Markham CM, Thiel M, Baumler ER, Addy RC, et al. Efficacy of It's Your Game-Tech: A Computer-Based Sexual Health Education Program for Middle School Youth. J Adolesc Health 2015 May;56(5):515-521 [FREE Full text] [doi: 10.1016/j.jadohealth.2015.01.001] [Medline: 25739520]

179. Phan N, Ebrahimi J, Kil D, Piniewski B, Dou D. Topic-Aware Physical Activity Propagation in a Health Social Network. IEEE Intell. Syst 2016 Jan;31(1):5-14. [doi: 10.1109/mis.2015.92]

180. Plaete J, Crombez G, Van der Mispel C, Verloigne M, Van Stappen V, De Bourdeaudhuij I. Effect of the Web-Based Intervention MyPlan 1.0 on Self-Reported Fruit and Vegetable Intake in Adults Who Visit General Practice: A Quasi-Experimental Trial. J Med Internet Res 2016 Feb 29;18(2):e47 [FREE Full text] [doi: 10.2196/jmir.5252] [Medline: 26929095]

181. Poppe L, Plaete J, Huys N, Verloigne M, Deveugele M, De Bourdeaudhuij I, et al. Process Evaluation of an eHealth Intervention Implemented into General Practice: General Practitioners' and Patients' Views. Int J Environ Res Public Health 2018 Jul 12;15(7):1475 [FREE Full text] [doi: 10.3390/ijerph15071475] [Medline: 30002338]

182. Prins RG, van Empelen P, Beenackers MA, Brug J, Oenema A. Systematic Development of the YouRAction program, a computer-tailored physical activity promotion intervention for Dutch adolescents, targeting personal motivations and environmental opportunities. BMC Public Health 2010 Aug 11;10(1):474 [FREE Full text] [doi: 10.1186/1471-2458-10-474] [Medline: 20701782]

183. Prins RG, Brug J, van Empelen P, Oenema A. Effectiveness of YouRAction, an intervention to promote adolescent physical activity using personal and environmental feedback: a cluster RCT. PLoS One 2012 Mar 5;7(3):e32682 [FREE Full text] [doi: 10.1371/journal.pone.0032682] [Medline: 22403695]

184. Raghupathy S, Forth ALG. The HAWK2 program: a computer-based drug prevention intervention for Native American youth. Am J Drug Alcohol Abuse 2012 Sep;38(5):461-467. [doi: 10.3109/00952990.2012.694531] [Medline: 22823599]

185. Reed-Jones RJ, Dorgo S, Hitchings MK, Bader JO. WiiFit ${ }^{\mathrm{TM}}$ Plus balance test scores for the assessment of balance and mobility in older adults. Gait Posture 2012 Jul;36(3):430-433 [FREE Full text] [doi: 10.1016/j.gaitpost.2012.03.027] [Medline: 22534562]

186. Rice E. The positive role of social networks and social networking technology in the condom-using behaviors of homeless young people. Public Health Rep 2010 Jul 01;125(4):588-595 [FREE Full text] [doi: 10.1177/003335491012500414] [Medline: 20597459]

187. Rice E, Milburn NG, Monro W. Social networking technology, social network composition, and reductions in substance use among homeless adolescents. Prev Sci 2011 Mar 31;12(1):80-88 [FREE Full text] [doi: 10.1007/s11121-010-0191-4] [Medline: 21194011]

188. Rice E, Tulbert E, Cederbaum J, Barman Adhikari A, Milburn NG. Mobilizing homeless youth for HIV prevention: a social network analysis of the acceptability of a face-to-face and online social networking intervention. Health Educ Res 2012 Apr 13;27(2):226-236 [FREE Full text] [doi: 10.1093/her/cyr113] [Medline: 22247453]

189. Rith-Najarian L, Sun W, Chen A, Chorpita B, Chavira D, Mougalian S, et al. What's in a name? Branding of online mental health programming for university students. J Consult Clin Psychol 2019 Apr;87(4):380-391. [doi: 10.1037/ccp0000383] [Medline: 30883165]

190. Robertson J, Jepson R, Macvean A, Gray S. Understanding the Importance of Context: A Qualitative Study of a Location-Based Exergame to Enhance School Childrens Physical Activity. PLoS One 2016 Aug 22;11(8):e0160927 [FREE Full text] [doi: 10.1371/journal.pone.0160927] [Medline: 27548504]

191. Rote AE, Klos LA, Brondino MJ, Harley AE, Swartz AM. The Efficacy of a Walking Intervention Using Social Media to Increase Physical Activity: A Randomized Trial. J Phys Act Health 2015 Jun;12 Suppl 1:S18-S25. [doi:

10.1123/jpah.2014-0279] [Medline: 25599378] 
192. Rovniak LS, Sallis JF, Kraschnewski JL, Sciamanna CN, Kiser EJ, Ray CA, et al. Engineering online and in-person social networks to sustain physical activity: application of a conceptual model. BMC Public Health 2013 Aug 14;13(1):753 [FREE Full text] [doi: 10.1186/1471-2458-13-753] [Medline: 23945138]

193. Schoene D, Lord SR, Delbaere K, Severino C, Davies TA, Smith ST. A randomized controlled pilot study of home-based step training in older people using videogame technology. PLoS One 2013 Mar 5;8(3):e57734 [FREE Full text] [doi: 10.1371/journal.pone.0057734] [Medline: 23472104]

194. Schwinn TM, Schinke S, Fang L, Kandasamy S. A web-based, health promotion program for adolescent girls and their mothers who reside in public housing. Addict Behav 2014 Apr;39(4):757-760 [FREE Full text] [doi: 10.1016/j.addbeh.2013.11.029] [Medline: 24447886]

195. Shafii T, Benson SK, Morrison DM, Hughes JP, Golden MR, Holmes KK. Results from e-KISS: electronic-KIOSK Intervention for Safer Sex: A pilot randomized controlled trial of an interactive computer-based intervention for sexual health in adolescents and young adults. PLoS One 2019 Jan 23;14(1):e0209064 [FREE Full text] [doi: 10.1371/journal.pone.0209064] [Medline: 30673710]

196. Shanta Bridges L, Sharma M, Lee JHSH, Bennett R, Buxbaum SG, Reese-Smith J. Using the PRECEDE-PROCEED model for an online peer-to-peer suicide prevention and awareness for depression (SPAD) intervention among African American college students: experimental study. Health Promot Perspect 2018 Dec 30;8(1):15-24 [FREE Full text] [doi: 10.15171/hpp.2018.02] [Medline: 29423358]

197. Sharma SV, Shegog R, Chow J, Finley C, Pomeroy M, Smith C, et al. Effects of the Quest to Lava Mountain Computer Game on Dietary and Physical Activity Behaviors of Elementary School Children: A Pilot Group-Randomized Controlled Trial. J Acad Nutr Diet 2015 Aug;115(8):1260-1271. [doi: 10.1016/j.jand.2015.02.022] [Medline: 25912520]

198. Shegog R, Craig RS, Gorman G, Jessen C, Torres J, Lane TL, et al. NATIVE-It's Your Game: Adapting a Technology-Based Sexual Health Curriculum for American Indian and Alaska Native youth. J Prim Prev 2017;38(1-2):27-48. [doi: 10.1007/s10935-016-0440-9] [Medline: 27520459]

199. Smith M, Denali DL. Social Media in Health Education, Promotion, and Communication: Reaching Rural Hispanic Populations along the USA/Mexico Border Region. J. Racial and Ethnic Health Disparities 2014 Jun 18;1(3):194-198. [doi: 10.1007/s40615-014-0025-3]

200. West DS, Monroe CM, Turner-McGrievy G, Sundstrom B, Larsen C, Magradey K, et al. A Technology-Mediated Behavioral Weight Gain Prevention Intervention for College Students: Controlled, Quasi-Experimental Study. J Med Internet Res 2016 Jun 13;18(6):e133 [FREE Full text] [doi: 10.2196/jmir.5474] [Medline: 27296086]

201. Springvloet L, Lechner L, Oenema A. Planned development and evaluation protocol of two versions of a web-based computer-tailored nutrition education intervention aimed at adults, including cognitive and environmental feedback. BMC Public Health 2014 Jan 17;14:47 [FREE Full text] [doi: 10.1186/1471-2458-14-47] [Medline: 24438381]

202. Suomi R, Mäntymäki M, Söderlund S. Promoting health in virtual worlds: lessons from second life. J Med Internet Res 2014 Oct 13;16(10):e229 [FREE Full text] [doi: 10.2196/jmir.3177] [Medline: 25313009]

203. Tague R, Maeder A, Vandelanotte C, Kolt G, Caperchione C, Rosenkranz R, et al. Assessing user engagement in a health promotion website using social networking. Studies in Health Technology and Informatics 2014;206:84-92. [doi: 10.3233/978-1-61499-456-5-84]

204. Digital Active Break. Techniker Krankenkasse. 2019. URL: https://www.tk.de/presse/themen/praevention/gesund-leben/ dab-projektfsu-jena-2068254 [accessed 2021-12-23]

205. Teitelman AM, Kim SK, Waas R, DeSenna A, Duncan R. Development of the NowIKnow Mobile Application to Promote Completion of HPV Vaccine Series Among Young Adult Women. J Obstet Gynecol Neonatal Nurs 2018 Nov;47(6):844-852. [doi: 10.1016/j.jogn.2018.06.001] [Medline: $\underline{\text { 30036509] }}$

206. Tolks D, Sailer M, Dadaczynski K, Lampert C, Huberty J, Paulus P, et al. ONYA-The Wellbeing Game: How to Use Gamification to Promote Wellbeing. Information 2019 Feb 12;10(2):58. [doi: 10.3390/info10020058]

207. Tortolero SR, Markham CM, Peskin MF, Shegog R, Addy RC, Escobar-Chaves SL, et al. It's Your Game: Keep It Real: delaying sexual behavior with an effective middle school program. J Adolesc Health 2010 Feb;46(2):169-179 [FREE Full text] [doi: 10.1016/j.jadohealth.2009.06.008] [Medline: 20113923]

208. Tsai T, Wong AM, Hsu C, Tseng KC. Research on a community-based platform for promoting health and physical fitness in the elderly community. PLoS One 2013 Feb 27;8(2):e57452 [FREE Full text] [doi: 10.1371/journal.pone.0057452] [Medline: 23460859]

209. Van Kessel G, Kavanagh M, Maher C. A Qualitative Study to Examine Feasibility and Design of an Online Social Networking Intervention to Increase Physical Activity in Teenage Girls. PLoS One 2016 Mar 2;11(3):e0150817 [FREE Full text] [doi: 10.1371/journal.pone.0150817] [Medline: 26934191]

210. Van Lippevelde W, Vangeel J, De Cock N, Lachat C, Goossens L, Beullens K, et al. Using a gamified monitoring app to change adolescents' snack intake: the development of the REWARD app and evaluation design. BMC Public Health 2016 Aug 05;16(1):725 [FREE Full text] [doi: 10.1186/s12889-016-3286-4] [Medline: 27494932]

211. van Stralen MM, de Vries H, Bolman C, Mudde AN, Lechner L. Exploring the efficacy and moderators of two computer-tailored physical activity interventions for older adults: a randomized controlled trial. Ann Behav Med 2010 May 25;39(2):139-150. [doi: 10.1007/s12160-010-9166-8] [Medline: 20182833] 
212. van Stralen MM, de Vries H, Mudde AN, Bolman C, Lechner L. The long-term efficacy of two computer-tailored physical activity interventions for older adults: main effects and mediators. Health Psychol 2011 Jul;30(4):442-452. [doi: 10.1037/a0023579] [Medline: 21639638]

213. Walton MA, Resko S, Barry KL, Chermack ST, Zucker RA, Zimmerman MA, et al. A randomized controlled trial testing the efficacy of a brief cannabis universal prevention program among adolescents in primary care. Addiction 2014 May;109(5):786-797 [FREE Full text] [doi: 10.1111/add.12469] [Medline: 24372937]

214. Ward DS, Vaughn AE, Mazzucca S, Burney R. Translating a child care based intervention for online delivery: development and randomized pilot study of Go NAPSACC. BMC Public Health 2017 Nov 21;17(1):891 [FREE Full text] [doi: 10.1186/s12889-017-4898-z] [Medline: 29162057]

215. Washington E, Weed L, Vardaman S. Using The Internet To Increase Physical Activity In A Faith Community. Journal of Christian Nursing 2015;32(3):168-173. [doi: 10.1097/cnj.0000000000000180]

216. Watkins DC. Improving the Living, Learning, and Thriving of Young Black Men: A Conceptual Framework for Reflection and Projection. Int J Environ Res Public Health 2019 Apr 13;16(8):1331 [FREE Full text] [doi: 10.3390/ijerph16081331] [Medline: $\underline{31013882]}$

217. Watkins DC, Allen JO, Goodwill JR, Noel B. Strengths and weaknesses of the Young Black Men, Masculinities, and Mental Health (YBMen) Facebook project. Am J Orthopsychiatry 2017;87(4):392-401. [doi: 10.1037/ort0000229] [Medline: 27977287]

218. Webster R, Gerressu M, Michie S, Estcourt C, Anderson J, Ang CS, et al. Defining the Content of an Online Sexual Health Intervention: The MenSS Website. JMIR Res Protoc 2015 Jul;4(3):e82 [FREE Full text] [doi: 10.2196/resprot.4316] [Medline: 26142304]

219. Whittemore R, Chao A, Jang M, Jeon S, Liptak T, Popick R, et al. Implementation of a school-based internet obesity prevention program for adolescents. J Nutr Educ Behav 2013 Nov;45(6):586-594 [FREE Full text] [doi: 10.1016/j.jneb.2013.03.012] [Medline: 23850014]

220. Widman L, Golin C, Kamke K, Massey J, Prinstein M. Feasibility and acceptability of a web-based HIV/STD prevention program for adolescent girls targeting sexual communication skills. Health Educ Res 2017 Aug 01;32(4):343-352 [FREE Full text] [doi: 10.1093/her/cyx048] [Medline: 28854574$]$

221. Widman L, Golin CE, Kamke K, Burnette JL, Prinstein MJ. Sexual Assertiveness Skills and Sexual Decision-Making in Adolescent Girls: Randomized Controlled Trial of an Online Program. Am J Public Health 2018 Jan;108(1):96-102. [doi: 10.2105/AJPH.2017.304106] [Medline: 29161072]

222. Widman L, Kamke K, Evans R, Stewart JL, Choukas-Bradley S, Golin CE. Feasibility, Acceptability, and Preliminary Efficacy of a Brief Online Sexual Health Program for Adolescents. J Sex Res 2020 Feb 09;57(2):145-154 [FREE Full text] [doi: 10.1080/00224499.2019.1630800] [Medline: 31287336 ]

223. Winskell K, Sabben G, Ondeng'e K, Odero I, Akelo V, Mudhune V. A Smartphone Game to Prevent HIV among Young Kenyans: Household Dynamics of Gameplay in a Feasibility Study. Health Educ J 2019 Aug 01;78(5):595-606 [FREE Full text] [doi: 10.1177/0017896919832344] [Medline: $\underline{34219796}$ ]

224. Witzel TC, Guise A, Nutland W, Bourne A. It Starts With Me: Privacy concerns and stigma in the evaluation of a Facebook health promotion intervention. Sex Health 2016 Jun;13(3):228-233. [doi: 10.1071/SH15231] [Medline: 27075940]

225. Wright CJC, Schwarzman J, Dietze PM, Crockett B, Lim MSC. Barriers and opportunities in the translation of mobile phone and social media interventions between research and health promotion practice in Australia: a qualitative study of expert perspectives. Health Res Policy Syst 2019 Jan 10;17(1):5 [FREE Full text] [doi: 10.1186/s12961-018-0406-x] [Medline: 30630497]

226. Ybarra ML, Biringi R, Prescott T, Bull SS. Usability and Navigability of an HIV/AIDS Internet Intervention for Adolescents in a Resource-Limited Setting. CIN: Computers, Informatics, Nursing 2012;30(11):587-595. [doi: $10.1097 / \mathrm{nxn} .0 \mathrm{~b} 013 \mathrm{e} 318266 \mathrm{cb} 0 \mathrm{e}]$

227. Yepes MF. Mobile Tablet Menus. Cornell Hospitality Quarterly 2014 Aug 28;56(1):58-67. [doi: 10.1177/1938965514546371]

228. Yoost JL, Starcher RW, King-Mallory RA, Hussain N, Hensley CA, Gress TW. The Use of Telehealth to Teach Reproductive Health to Female Rural High School Students. J Pediatr Adolesc Gynecol 2017 Apr;30(2):193-198. [doi: 10.1016/j.jpag.2016.10.002] [Medline: 27742427]

229. Youm S, Park S. How the awareness of u-healthcare service and health conditions affect healthy lifestyle: an empirical analysis based on a u-healthcare service experience. Telemed J E Health 2015 Apr;21(4):286-295 [FREE Full text] [doi: 10.1089/tmj.2014.0092] [Medline: 25635473]

230. Young SD, Cumberland WG, Lee S, Jaganath D, Szekeres G, Coates T. Social networking technologies as an emerging tool for HIV prevention: a cluster randomized trial. Ann Intern Med 2013 Sep 3;159(5):318-324 [FREE Full text] [doi: 10.7326/0003-4819-159-5-201309030-00005] [Medline: 24026317]

231. Young SD, Harrell L, Jaganath D, Cohen AC, Shoptaw S. Feasibility of recruiting peer educators for an online social networking-based health intervention. Health Educ J 2013 May;72(3):276-282 [FREE Full text] [doi: 10.1177/0017896912440768] [Medline: 25530624] 
232. Young SD, Holloway I, Jaganath D, Rice E, Westmoreland D, Coates T. Project HOPE: Online Social Network Changes in an HIV Prevention Randomized Controlled Trial for African American and Latino Men Who Have Sex With Men. Am J Public Health 2014 Sep;104(9):1707-1712. [doi: 10.2105/ajph.2014.301992]

233. Zhang J, Brackbill D, Yang S, Centola D. Efficacy and causal mechanism of an online social media intervention to increase physical activity: Results of a randomized controlled trial. Prev Med Rep 2015;2:651-657 [FREE Full text] [doi: 10.1016/j.pmedr.2015.08.005] [Medline: 26844132]

234. Zhang J, Brackbill D, Yang S, Becker J, Herbert N, Centola D. Support or competition? How online social networks increase physical activity: A randomized controlled trial. Prev Med Rep 2016 Dec;4:453-458 [FREE Full text] [doi: 10.1016/j.pmedr.2016.08.008] [Medline: 27617191]

235. Zhao W, Lun R. A Kinect-based system for promoting healthier living at home. In: Proceedings of the IEEE International Conference on Systems, Man, and Cybernetics (SMC). 2016 Presented at: IEEE International Conference on Systems, Man, and Cybernetics (SMC); 9-12 Oct. 2016; Budapest, Hungary p. 258-263. [doi: 10.1109/smc.2016.7844251]

236. Norman GJ, Zabinski MF, Adams MA, Rosenberg DE, Yaroch AL, Atienza AA. A review of eHealth interventions for physical activity and dietary behavior change. Am J Prev Med 2007 Oct;33(4):336-345 [FREE Full text] [doi: 10.1016/j.amepre.2007.05.007] [Medline: 17888860 ]

237. Bailey J, Mann S, Wayal S, Hunter R, Free C, Abraham C, et al. Sexual health promotion for young people delivered via digital media: a scoping review. Public Health Res 2015 Nov;3(13):1-120. [doi: 10.3310/phr03130] [Medline: 26583166]

238. Lupton D. Health promotion in the digital era: a critical commentary. Health Promot Int 2015 Mar 15;30(1):174-183. [doi: 10.1093/heapro/dau091] [Medline: 25320120]

239. Taggart T, Grewe ME, Conserve DF, Gliwa C, Roman IM. Social Media and HIV: A Systematic Review of Uses of Social Media in HIV Communication. J Med Internet Res 2015 Nov;17(11):e248 [FREE Full text] [doi: 10.2196/jmir.4387] [Medline: 26525289]

240. Stellefson M, Paige SR, Chaney BH, Chaney JD. Evolving Role of Social Media in Health Promotion: Updated Responsibilities for Health Education Specialists. Int J Environ Res Public Health 2020 Feb 12;17(4):1153 [FREE Full text] [doi: 10.3390/ijerph17041153] [Medline: 32059561]

241. Vedel I, Ramaprasad J, Lapointe L. Social Media Strategies for Health Promotion by Nonprofit Organizations: Multiple Case Study Design. J Med Internet Res 2020 Apr 06;22(4):e15586 [FREE Full text] [doi: 10.2196/15586] [Medline: 32250282]

242. Nour M, Chen J, Allman-Farinelli M. Efficacy and External Validity of Electronic and Mobile Phone-Based Interventions Promoting Vegetable Intake in Young Adults: Systematic Review and Meta-Analysis. J Med Internet Res 2016 Apr 08;18(4):e58 [FREE Full text] [doi: 10.2196/jmir.5082] [Medline: 27059765]

243. Healthy settings. World Health Organization. URL: https://www.who.int/teams/health-promotion/enhanced-wellbeing/ healthy-settings [accessed 2021-12-01]

\section{Abbreviations}

mHealth: mobile health

PRISMA: Preferred Reporting Items for Systematic Reviews and Meta-Analyses

PRISMA-ScR: Preferred Reporting Items for Systematic Reviews and Meta-Analyses extension for Scoping Reviews

RCT: randomized controlled trial

WHO: World Health Organization

Edited by A Mavragani; submitted 06.10.20; peer-reviewed by A Hidki, S Tomczyk; comments to author 03.12.20; revised version
received 16.12.20; accepted 02.12.21; published 28.01.22
Please cite as:
Stark AL, Geukes C, Dockweiler C
Digital Health Promotion and Prevention in Settings: Scoping Review
J Med Internet Res 2022;24(1):e21063
URL: $\underline{\text { https://www.jmir.org/2022/1/e21063 }}$
doi: $\underline{10.2196 / 21063}$
PMID:

(C)Anna Lea Stark, Cornelia Geukes, Christoph Dockweiler. Originally published in the Journal of Medical Internet Research (https://www.jmir.org), 28.01.2022. This is an open-access article distributed under the terms of the Creative Commons Attribution License (https://creativecommons.org/licenses/by/4.0/), which permits unrestricted use, distribution, and reproduction in any 
medium, provided the original work, first published in the Journal of Medical Internet Research, is properly cited. The complete bibliographic information, a link to the original publication on https://www.jmir.org/, as well as this copyright and license information must be included. 